\title{
Photocatalytic Oxygenation of Substrates by Dioxygen with Protonated Manganese(III) Corrolazine
}

\author{
Jieun Jung ${ }^{\dagger}$, Heather M. Neu ${ }^{\ddagger}$, Pannee Leeladee ${ }^{\ddagger}$, Maxime A. Siegler ${ }^{\ddagger}$, Kei Ohkubo ${ }^{\dagger}$, , David \\ P. Goldberg ${ }^{*} \neq$, and Shunichi Fukuzumi ${ }^{*}, \dagger, \S, \|$ \\ tDepartment of Chemistry and Nano Science, Ewha Womans University, Seoul 120-750, Korea \\ ‡Department of Chemistry, The Johns Hopkins University, 3400 North Charles Street, Baltimore, \\ Maryland 21218, United States \\ $\S$ Department of Material and Life Science, Graduate School of Engineering, Osaka University, \\ ALCA and SENTAN, Japan Science and Technology Agency (JST), Suita, Osaka 565-0871, \\ Japan \\ $\|$ Faculty of Science and Engineering, Meijo University, ALCA and SEN TAN, Japan Science and \\ Technology Agency (JST), Nagoya, Aichi 468-0073, Japan
}

\section{Abstract}

UV-vis spectral titrations of a manganese(III) corrolazine complex $\left[\mathrm{Mn}^{\mathrm{III}}\left(\mathrm{TBP}_{8} \mathrm{Cz}\right): \mathrm{TBP}_{8} \mathrm{Cz}=\right.$ octakis ( $p$-tert-butylphenyl)corrolazinato $\left.{ }^{3-}\right]$ with HOTf in benzonitrile $(\mathrm{PhCN})$ indicate mono- and diprotonation of $\mathrm{Mn}^{\mathrm{III}}\left(\mathrm{TBP}_{8} \mathrm{Cz}\right)$ to give $\mathrm{Mn}^{\mathrm{III}}(\mathrm{OTf})\left(\mathrm{TBP}_{8} \mathrm{Cz}(\mathrm{H})\right)$ and $\left[\mathrm{Mn}^{\mathrm{III}}(\mathrm{OTf})\left(\mathrm{H}_{2} \mathrm{O}\right)\right.$ $\left.\left(\mathrm{TBP}_{8} \mathrm{Cz}(\mathrm{H})_{2}\right)\right][\mathrm{OTf}]$ with the protonation constants of $9.0 \times 10^{6} \mathrm{M}^{-1}$ and $4.7 \times 10^{3} \mathrm{M}^{-1}$, respectively. The protonated site of $\mathrm{Mn}^{\mathrm{III}}(\mathrm{OTf})\left(\mathrm{TBP}_{8} \mathrm{Cz}(\mathrm{H})\right)$ and $\left[\mathrm{Mn}^{\mathrm{III}}(\mathrm{OTf})\left(\mathrm{H}_{2} \mathrm{O}\right)\right.$ $\left.\left(\mathrm{TBP}_{8} \mathrm{Cz}(\mathrm{H})_{2}\right)\right][\mathrm{OTf}]$ were identified by $\mathrm{X}$-ray crystal structures of the mono- and diprotonated complexes. In the presence of HOTf, the monoprotonated manganese(III) corrolazine complex $\left[\mathrm{Mn}^{\mathrm{III}}(\mathrm{OTf})\left(\mathrm{TBP}_{8} \mathrm{Cz}(\mathrm{H})\right)\right]$ acts as an efficient photocatalytic catalyst for the oxidation of hexamethylbenzene and thioanisole by $\mathrm{O}_{2}$ to the corresponding alcohol and sulfoxide with 563 and $902 \mathrm{TON}$, respectively. Femtosecond laser flash photolysis measurements of $\mathrm{Mn}^{\mathrm{III}}(\mathrm{OTf})$ $\left(\mathrm{TBP}_{8} \mathrm{Cz}(\mathrm{H})\right)$ and $\left[\mathrm{Mn}^{\mathrm{III}}(\mathrm{OTf})\left(\mathrm{H}_{2} \mathrm{O}\right)\left(\mathrm{TBP}_{8} \mathrm{Cz}(\mathrm{H})_{2}\right)\right][\mathrm{OTf}]$ in the presence of $\mathrm{O}_{2}$ revealed the formation of a tripquintet excited state, which was rapidly converted to a tripseptet excited state. The tripseptet excited state of $\mathrm{Mn}^{\mathrm{III}}(\mathrm{OTf})\left(\mathrm{TBP}_{8} \mathrm{Cz}(\mathrm{H})\right)$ reacted with $\mathrm{O}_{2}$ with a diffusion-limited rate constant to produce the putative $\mathrm{Mn}^{\mathrm{IV}}\left(\mathrm{O}_{2}{ }^{--}\right)(\mathrm{OTf})\left(\mathrm{TBP}_{8} \mathrm{Cz}(\mathrm{H})\right)$, whereas the tripseptet excited state of $\left[\mathrm{Mn}^{\mathrm{III}}(\mathrm{OTf})\left(\mathrm{H}_{2} \mathrm{O}\right)\left(\mathrm{TBP}_{8} \mathrm{Cz}(\mathrm{H})_{2}\right)\right][\mathrm{OTf}]$ exhibited no reactivity toward $\mathrm{O}_{2}$. In the presence of HOTf, $\mathrm{Mn}^{\mathrm{V}}(\mathrm{O})\left(\mathrm{TBP}_{8} \mathrm{Cz}\right)$ can oxidize not only $\mathrm{HMB}$ but also mesitylene to the corresponding alcohols, accompanied by regeneration of $\mathrm{Mn}^{\mathrm{III}}(\mathrm{OTf})\left(\mathrm{TBP}_{8} \mathrm{Cz}(\mathrm{H})\right)$. This thermal reaction was examined for a kinetic isotope effect, and essentially no KIE (1.1) was observed for the oxidation of mesitylene- $d_{12}$, suggesting a proton-coupled electron transfer (PCET) mechanism is operative

\footnotetext{
*To whom correspondence should be addressed. ; Email: fukuzumi@chem.eng.osaka-u.ac.jp; Email: dpg@jhu.edu ASSOCIATED CONTENT

Supporting Information

The Supporting Information is available free of charge via the Internet at http://pubs.acs.org.

UV-vis absorption spectral data (Figure S1-S5 and S9-S10), product analysis data (Figure S6-S8), kinetic analyses (Figure S11-S12), and X-ray crystallographic data (Figure S13-S14)
} 
in this case. Thus, the monoprotonated manganese(III) corrolazine complex, $\mathrm{Mn}^{\mathrm{III}}$ (OTf)

$\left(\mathrm{TBP}_{8} \mathrm{Cz}(\mathrm{H})\right)$, acts as an efficient photocatalytic for the oxidation of $\mathrm{HMB}$ by $\mathrm{O}_{2}$ to the alcohol.

\section{Graphical Abstract}

Photocatalytic oxygenation of substrates by a manganese complex in the presence of HOTf has been studied. The protonated site of the mono- and diprotonated $\mathrm{Mn}^{\mathrm{III}}$ complexes were characterized by single crystal XRD. In the presence of HOTf, the monoprotonated manganese(III) corrolazine complex acts as an efficient photocatalytic catalyst for the oxidation of hexamethylbenzene and thioanisole by $\mathrm{O}_{2}$ whereas the diprotonated manganese(III) corrolazine complex exhibited no reactivity toward $\mathrm{O}_{2}$

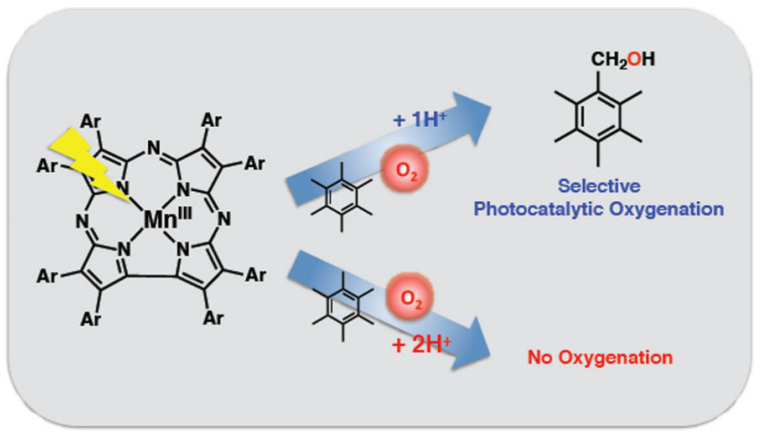

\section{INTRODUCTION}

Oxidation reactions are essential in the metabolism of organic substrates and many enzymes are known to catalyze these reactions in biological systems. High-valent metal-oxo complexes have been implicated as important reactive intermediates in these reactions for heme and non-heme iron enzymes. ${ }^{1 \_14}$ To help clarify related oxidation mechanisms and to control the reactivity, many synthetic high-valent metal-oxo complexes have been prepared using oxidants such as iodosylarenes, peroxy acids, and hydrogen peroxide. ${ }^{3}{ }^{14}$ Dioxygen $\left(\mathrm{O}_{2}\right)$ is an ideal reagent for the production of these metal-oxo complexes, and for the subsequent oxygenation of substrates because of its abundant availability and nontoxicity. ${ }^{15}, 16$ The mechanisms of oxidation of substrates by high-valent metal-oxo complexes have been studied extensively. ${ }^{17 \_23}$ High-valent manganese-oxo complexes have attracted special attention because they are postulated as important intermediates for water oxidation in the oxygen-evolving center (OEC) of photosystem II. ${ }^{24} 32$

We have shown that a well-characterized manganese(V)-oxo complex can be prepared by visible light irradiation of a manganese(III) corrolazine $\left[\mathrm{Mn}^{\mathrm{III}}\left(\mathrm{TBP}_{8} \mathrm{Cz}\right): \mathrm{TBP}_{8} \mathrm{Cz}^{3-}=\right.$ octakis $\left(p\right.$-tert-butylphenyl)corrolazinato $\left.{ }^{3-}\right]$ in the presence of toluene derivatives with dioxygen. ${ }^{15,16}$ Hexamethylbenzene (HMB) was shown to be oxidized to pentamethylbenzyl alcohol during this reaction, serving as a proton/electron source to assist with $\mathrm{O}_{2}$ activation. However, the produced $\mathrm{Mn}^{\mathrm{V}}(\mathrm{O})\left(\mathrm{TBP}_{8} \mathrm{Cz}\right)$ was unreactive toward $\mathrm{HMB}$, which prevented the regeneration of the $\mathrm{Mn}^{\mathrm{III}}$ starting complex and removed the possibility for catalytic turnover. Only in the case of the O-atom acceptor $\mathrm{PPh}_{3}$, or 9,10-dihydro-1-methylacridine, which has a very weak $\mathrm{C}-\mathrm{H}$ bond was photocatalysis observed. ${ }^{16,33}$ The reactivity of high-valent 
metal-oxo complexes to oxidize substrates has been reported to be much enhanced by the presence of acids, ${ }^{34-42}$ suggesting that the addition of an $\mathrm{H}^{+}$source could activate the $\mathrm{Mn}^{\mathrm{V}}(\mathrm{O})$ complex and possibly lead to catalytic turnover.

We showed that addition of a strong proton source $\left[\mathrm{H}\left(\mathrm{OEt}_{2}\right)_{2}\right]^{+}\left[\mathrm{B}\left(\mathrm{C}_{6} \mathrm{~F}_{5}\right)_{4}\right]^{-}\left(\mathrm{H}^{+}\left[\mathrm{B}\left(\mathrm{C}_{6} \mathrm{~F}_{5}\right)_{4}\right]^{-}\right)$ allowed for the photocatalytic oxidation of $\mathrm{HMB}$ by $\mathrm{Mn}^{\mathrm{III}}\left(\mathrm{TBP}_{8} \mathrm{Cz}\right)$ with $\mathrm{O}_{2}$ as oxidant. The addition of one and two equivalents of $\mathrm{H}^{+}\left[\mathrm{B}\left(\mathrm{C}_{6} \mathrm{~F}_{5}\right)_{4}\right]^{-}$to $\mathrm{Mn}^{\mathrm{III}}\left(\mathrm{TBP}_{8} \mathrm{Cz}\right)$ formed two new species that were characterized by $\mathrm{X}$-ray diffraction (XRD) as the monoprotonated $\left[\mathrm{Mn}^{\mathrm{III}}\left(\mathrm{H}_{2} \mathrm{O}\right)-\left(\mathrm{TBP}_{8} \mathrm{Cz}(\mathrm{H})\right)\right]\left[\mathrm{B}\left(\mathrm{C}_{6} \mathrm{~F}_{5}\right)_{4}\right]$, and the diprotonated $\left[\mathrm{Mn}^{\mathrm{III}}\left(\mathrm{H}_{2} \mathrm{O}\right)\left(\mathrm{TBP}_{8} \mathrm{Cz}(\mathrm{H})_{2}\right)\right]$ $\left[\mathrm{B}\left(\mathrm{C}_{6} \mathrm{~F}_{5}\right)_{4}\right]_{2}$, respectively. The monoprotonated $\left[\mathrm{Mn}^{\mathrm{III}}\left(\mathrm{H}_{2} \mathrm{O}\right)\left(\mathrm{TBP} \mathrm{T}_{8} \mathrm{Cz}(\mathrm{H})\right)\right]\left[\mathrm{B}\left(\mathrm{C}_{6} \mathrm{~F}_{5}\right)_{4}\right]$ is protonated at the meso- $\mathrm{N}$ atom adjacent to the direct pyrrole-pyrrole bond of the corrolazine ligand. For the di-protonated $\left[\mathrm{Mn}^{\mathrm{III}}\left(\mathrm{H}_{2} \mathrm{O}\right)\left(\mathrm{TBP}_{8} \mathrm{Cz}(\mathrm{H})_{2}\right)\right]\left[\mathrm{B}\left(\mathrm{C}_{6} \mathrm{~F}_{5}\right)_{4}\right]_{2}$ complex, both $\mathrm{H}$ atoms were found to be located on the opposite meso-N atoms adjacent to the direct pyrrolepyrrole bond. The mono-protonated $\mathrm{Mn}^{\mathrm{III}}$ complex was catalytically active with a turnover number (TON) of 18 for pentamethylbenzyl alcohol and 9 for pentamethylbenzaldehyde. Interestingly, the diprotonated $\left[\mathrm{Mn}^{\mathrm{III}}\left(\mathrm{H}_{2} \mathrm{O}\right)\left(\mathrm{TBP}_{8} \mathrm{Cz}(\mathrm{H})_{2}\right)\right]^{2+}$ complex showed no catalytic activity, indicating that catalytic turnover was highly dependent on the level of protonation.

In this work we present several new findings on the proton-assisted, photoactivated oxygenation chemistry catalyzed by manganese corrolazine. We demonstrate that substitution of the $\mathrm{H}^{+}\left[\mathrm{B}\left(\mathrm{C}_{6} \mathrm{~F}_{5}\right)_{4}\right]^{-}$proton donor with triflic acid (HOTf) leads to dramatic changes in catalytic activity, and generates new protonated $\mathrm{Mn}(\mathrm{III})$ corrolazine complexes, $\mathrm{Mn}^{\mathrm{III}}(\mathrm{OTf})\left(\mathrm{TBP}_{8} \mathrm{Cz}(\mathrm{H})\right)$ and $\left[\mathrm{Mn}^{\mathrm{III}}(\mathrm{OTf})\left(\mathrm{H}_{2} \mathrm{O}\right)\left(\mathrm{TBP}_{8} \mathrm{Cz}(\mathrm{H})_{2}\right)\right][\mathrm{OTf}]$, which were characterized by $\mathrm{X}$-ray diffraction. The crystal structures reveal that protonation occurs on the meso nitrogen atoms as seen for $\mathrm{H}^{+}\left[\mathrm{B}\left(\mathrm{C}_{6} \mathrm{~F}_{5}\right)_{4}\right]^{-}$, but significant changes in axial ligation state are observed with HOTf, including coordination of the anionic triflate and formation of both 5- and 6-coordinate species. Coordination of OTf- provides a possible mechanism for enhancing catalytic reactivity through a proposed $\mathrm{Mn} \mathrm{V}(\mathrm{O})\left(\mathrm{TBP}_{8} \mathrm{Cz}\right)$ intermediate. ${ }^{44,45,51}$ In our previous report on proton-assisted catalysis, we suggested a mechanism that involved a short-lived tripseptet excited state of the monoprotonated $\mathrm{Mn}^{\mathrm{III}}$ complex as a key intermediate. This mechanism was based on prior photochemical characterization of the parent $\mathrm{Mn}^{\mathrm{III}}$ complex. However, direct spectroscopic evidence for the proposed photochemical excited states of the protonated $\mathrm{Mn}^{\mathrm{III}}$ species was absent. Herein we present femtosecond laser flash photolysis measurements on both the monoprotonated $\mathrm{Mn}^{\mathrm{III}}(\mathrm{OTf})$ $\left(\mathrm{TBP}_{8} \mathrm{Cz}(\mathrm{H})\right)$ and the diprotonated $\left[\mathrm{Mn}^{\mathrm{III}}(\mathrm{OTf})\left(\mathrm{H}_{2} \mathrm{O}\right)\left(\mathrm{TBP}_{8} \mathrm{Cz}(\mathrm{H})_{2}\right)\right]-[\mathrm{OTf}]$, which reveal shorter-lived excited states $\left({ }^{7} \mathrm{~T}_{1}\right)$ in the presence of $\mathrm{O}_{2}$ that provide direct evidence for the proposed mechanism of photocatalytic oxygenation. We also demonstrate new catalytic activity for the monoprotonated complex. This complex was shown to be an excellent catalyst for the selective S-oxygenation of thioanisole with only $\mathrm{O}_{2}$ and light as reagents.

\section{- EXPERIMENTAL SECTION}

\section{Materials}

The starting material $\mathrm{Mn}^{\mathrm{III}}\left(\mathrm{TBP}_{8} \mathrm{Cz}\right)$ was synthesized according to published procedures. ${ }^{46}$ The commercially available reagents (hexamethylbenzene and trifluoromethane-sulfonic acid) were purchased with the best available purity and used without further purification. 
Benzonitrile $(\mathrm{PhCN})$ was purchased with the best available purity from Wako Pure Chemical Industries, Ltd. and dried according to literature procedures ${ }^{47}$ and distilled under Ar prior to use.

\section{Spectral and Kinetic Measurements}

The formation of protonated species of $\mathrm{Mn}^{\mathrm{III}}\left(\mathrm{TBP}_{8} \mathrm{Cz}\right)$ and $\mathrm{Mn}^{\mathrm{V}}(\mathrm{O})\left(\mathrm{TBP}_{8} \mathrm{Cz}\right)$ were examined from the change in the UV-vis spectra of $\mathrm{Mn}^{\mathrm{III}}\left(\mathrm{TBP}_{8} \mathrm{Cz}\right)\left(\lambda_{\max }=695 \mathrm{~nm}, \varepsilon_{\max }=\right.$ $\left.3.5 \times 10^{4} \mathrm{M}^{-1} \mathrm{~cm}^{-1}\right)$ and $\mathrm{Mn}^{\mathrm{V}}(\mathrm{O})\left(\mathrm{TBP}_{8} \mathrm{Cz}\right)\left(\lambda_{\max }=634 \mathrm{~nm}, \varepsilon_{\max }=2.0 \times 10^{4} \mathrm{M}^{-1} \mathrm{~cm}^{-1}\right)^{16}$ by spectral titration with HOTf at $298 \mathrm{~K}$ using a Hewlett-Packard HP8453 diode array spectrophotometer. The first and second binding constants of HOTf with $\mathrm{Mn}^{\mathrm{III}}\left(\mathrm{TBP}_{8} \mathrm{Cz}\right)$ were determined in $\mathrm{PhCN}$ from the $\mathrm{UV}$-vis spectral change due to the formation of the protonated species $\mathrm{Mn}^{\mathrm{III}}(\mathrm{OTf})\left(\mathrm{TBP}_{8} \mathrm{Cz}(\mathrm{H})\right)\left(\lambda_{\max }=725 \mathrm{~nm}\right)$ and $\left[\mathrm{Mn}^{\mathrm{III}}(\mathrm{OTf})\left(\mathrm{H}_{2} \mathrm{O}\right)\right.$ $\left.\left(\mathrm{TBP}_{8} \mathrm{Cz}(\mathrm{H})_{2}\right)\right][\mathrm{OTf}]\left(\lambda_{\max }=745 \mathrm{~nm}\right)$. The first binding constant of HOTf with $\mathrm{Mn}^{\mathrm{V}}(\mathrm{O})$ $\left(\mathrm{TBP}_{8} \mathrm{Cz}\right)$ was determined in $\mathrm{PhCN}$ from the UV-vis spectral change due to the formation of the protonated species $\mathrm{Mn}^{\mathrm{IV}}(\mathrm{OH})(\mathrm{OTf})\left(\mathrm{TBP}_{8} \mathrm{Cz}^{\circ+}\right)\left(\lambda_{\max }=795 \mathrm{~nm}\right)$.

\section{Crystallization of $\mathrm{Mn}^{\text {III }}(\mathrm{OTf})\left(\mathrm{TBP}_{8} \mathrm{Cz}(\mathrm{H})\right)$}

To a solution of $\mathrm{Mn}^{\mathrm{III}}\left(\mathrm{TBP}_{8} \mathrm{Cz}\right)(20 \mathrm{mg}, 14 \mu \mathrm{mol})$ in $\mathrm{CH}_{2} \mathrm{Cl}_{2}(1.0 \mathrm{~mL})$ was added $\mathrm{Sc}(\mathrm{OTf})_{3}$ (70 mg, $1.4 \times 10^{-4} \mathrm{~mol}, 10$ equiv) dissolved in $\mathrm{CH}_{3} \mathrm{CN}(0.4 \mathrm{~mL})$. A color change from brown to reddish-brown was observed. The solution was then filtered through celite and eluted with $\mathrm{CH}_{2} \mathrm{Cl}_{2}(\sim 1.0 \mathrm{~mL})$. X-ray quality crystals were obtained by slow evaporation of this solution for about 4 weeks. Characterization by elemental analysis indicating the monoprotonated $\mathrm{Mn}^{\mathrm{III}}(\mathrm{OTf})\left(\mathrm{TBP}_{8} \mathrm{Cz}(\mathrm{H})\right) \cdot \mathrm{CH}_{2} \mathrm{Cl}_{2}$; calcd. for $\mathrm{C}_{98} \mathrm{H}_{107} \mathrm{Cl}_{2} \mathrm{~F}_{3} \mathrm{MnN}_{7} \mathrm{O}_{3} \mathrm{~S}: \mathrm{C}$, 71.52; H, 6.55; N, 5.96. Found: C, 71.65; H, 6.53; N, 6.01.

\section{Crystallization of [Mn"II $\left.(\mathrm{OTf})\left(\mathrm{H}_{2} \mathrm{O}\right)\left(\mathrm{TBP}_{8} \mathrm{Cz}(\mathrm{H})_{2}\right)\right][\mathrm{OTf}]$}

To a solution of $\mathrm{Mn}^{\mathrm{III}}\left(\mathrm{TBP}_{8} \mathrm{Cz}\right)(1.5 \mathrm{mg}, 1.1 \mu \mathrm{mol})$ in $\mathrm{CH}_{2} \mathrm{Cl}_{2}(0.5 \mathrm{~mL})$ was added 2 equiv HOTf. A color change from brown to red was observed. The solution was transferred to a NMR tube and layered with $n$-heptane. X-ray quality crystals were obtained after a month. Elemental analysis was performed for $\left[\mathrm{Mn}^{\mathrm{III}}(\mathrm{OTf})\left(\mathrm{H}_{2} \mathrm{O}\right)\left(\mathrm{TBP}_{8} \mathrm{Cz}(\mathrm{H})_{2}\right)\right]$ [OTf ${ }^{-} \cdot \mathrm{CH}_{2} \mathrm{Cl}_{2} \bullet \mathrm{C}_{7} \mathrm{H}_{16}$; calcd. for $\mathrm{C}_{106} \mathrm{H}_{126} \mathrm{Cl}_{2} \mathrm{~F}_{6} \mathrm{MnN}_{7} \mathrm{O}_{7} \mathrm{~S}_{2}: \mathrm{C}, 66.51 ; \mathrm{H}, 6.64 ; \mathrm{N}, 5.12$. Found: C, 66.28; H, 6.32; N, 5.56.

\section{X-ray Crystallography}

$\mathbf{M n}^{\text {III }}(\mathbf{O T f})\left(\mathrm{TBP}_{\mathbf{8}} \mathbf{C z}(\mathbf{H})\right)$-All reflection intensities were measured at $110(2) \mathrm{K}$ using a KM4/Xcalibur (detector: Sapphire3) with enhance graphite-monochromated Mo $\mathrm{Ka}$ radiation $(\lambda=0.71073 \AA$ ) under the program CrysAlisPro (Version 1.171.35.11 Oxford Diffraction Ltd., 2011). The program CrysAlisPro (Version 1.171.35.11, Oxford Diffraction Ltd., 2011) was used to refine the cell dimensions. Data reduction was done using the program CrysAlisPro (Version 1.171.35.11, Oxford Diffraction Ltd., 2011). The structure was solved with the program SHELXS-97 and was refined on $F^{2}$ with SHELXL-97. ${ }^{48}$ Analytical numeric absorption corrections based on a multifaceted crystal model were applied using CrysAlisPro (Version 1.171.35.11, Oxford Diffraction Ltd., 2011). The temperature of the data collection was controlled using the system Cryojet (manufactured by 
Oxford Instruments). The $\mathrm{H}$ atoms (except when specified) were placed at calculated positions using the instructions AFIX 43 or AFIX 137 with isotropic displacement parameters having values 1.2 or 1.5 times $U_{\text {eq }}$ of the attached $\mathrm{C}$ atoms. The $\mathrm{H}$ atom attached to N5 was located from difference Fourier maps, and its atomic coordinates were refined freely. Seven of the eight 4-tert-butylphenyl groups are either wholly disordered (over two orientations) or partially disordered around the tert-butyl groups (over two orientations). The coordinated counterion is also disordered over two orientations.

$\mathbf{M n}^{\text {III }}(\mathbf{O T f})\left(\mathrm{TBP}_{\mathbf{8}} \mathbf{C z}(\mathbf{H})\right)-\mathrm{Fw}=1560.88$, black plate, $0.58 \times 0.33 \times 0.06 \mathrm{~mm}^{3}$, monoclinic, $P 2_{1} / n$ (no. 14), $a=19.9174(5), b=21.8922(4), c=20.3238(5) \AA, \beta=110.584(3)^{\circ}, V=$ 8296.1(3) $\AA^{3}, Z=4, D_{\mathrm{x}}=1.250 \mathrm{~g} \mathrm{~cm}^{-3}, \mu=0.247 \mathrm{~mm}^{-1}$, abs. corr. range: $0.923-0.987$. 45329 Reflections were measured up to a resolution of $(\sin \theta / \lambda)_{\max }=0.59 \AA^{-1} .14603$ Reflections were unique $\left(R_{\text {int }}=0.0440\right)$, of which 10025 were observed $[I>2 \sigma(I)] .1482$ Parameters were refined using 1634 restraints. $R 1 / w R 2[I>2 \sigma(I)]: 0.0624 / 0.1552 . R 1 / w R 2$ [all refl.]: $0.0977 / 0.1734$. $\mathrm{S}=1.041$. Residual electron density found between -0.53 and 0.85 e $\AA^{-3}$.

$\left[\mathrm{Mn}^{\text {III }}(\mathrm{OTf})\left(\mathrm{H}_{\mathbf{2}} \mathbf{O}\right)\left(\mathrm{TBP}_{\mathbf{8}} \mathrm{Cz}(\mathbf{H})_{2}\right)\right][\mathrm{OTf}]$-All reflection intensities were measured at $110(2)$ $\mathrm{K}$ using a SuperNova diffractometer (equipped with Atlas detector) with $\mathrm{Cu} K \mathrm{Ka}$ radiation $(\lambda$ = 1.54178 $\AA$ ) under the program CrysAlisPro (Version 1.171.36.32 Agilent Technologies, 2013). The same program was used to refine the cell dimensions and for data reduction. The structure was solved and refined on $F^{2}$ with SHELXL-2013. ${ }^{48}$ Analytical numeric absorption correction based on a multifaceted crystal model was applied using CrysAlisPro. The temperature of the data collection was controlled using the system Cryojet (manufactured by Oxford Instruments). The $\mathrm{H}$ atoms were placed at calculated positions (unless otherwise specified) using the instructions AFIX 23, AFIX 43 or AFIX 137 with isotropic displacement parameters having values 1.2 times $U_{\text {eq }}$ of the attached $\mathrm{C}$ or $\mathrm{N}$ atoms. The $\mathrm{H}$ atoms attached to $\mathrm{O} 1 \mathrm{~W}$ and $\mathrm{O} 2 \mathrm{~W} / \mathrm{O} 2 \mathrm{~W}$ were found from difference fourier maps, and their coordinates were refined freely using the DFIX restraints. The tert-butyl group $\mathrm{C} 53 \rightarrow \mathrm{C} 56$, the tert-butylphenyl group $\mathrm{C} 77 \rightarrow \mathrm{C} 86$, and the hydronium cation are found to be disordered over two orientations, and the occupancy factors of the major components of the disorder refine to $0.50(3), 0.588(6)$, and $0.634(4)$, respectively. The crystal lattice contains some disordered solvent molecules (DCM and heptane). All orientations of the three nonfully occupied DCM molecules were successfully modeled, and the asymmetric unit contains ca. 2.53 DCM molecules per Mn complex. The heptane molecule was found to be disordered, and its contribution has been taken out in the final refinement. ${ }^{49}$

[Mn $\left.{ }^{\text {III }}(\mathbf{O T f})\left(\mathbf{H}_{\mathbf{2}} \mathbf{O}\right)\left(\mathrm{TBP}_{\mathbf{8}} \mathbf{C z}(\mathbf{H})_{\mathbf{2}}\right)\right][\mathrm{OTf}]-\mathrm{Fw}=2111.86$, dark brown-black block, $0.35 \times$ $0.30 \times 0.21 \mathrm{~mm}^{3}$, triclinic, $P-1$ (no.2), $a=18.3393(4), b=18.9149$ (3) $, c=21.2275(3), a=$ 91.1721(13), $\beta=114.7271(17), \gamma=118.8374(19)^{\circ}, V=5625.8(2) \AA^{3}, Z=2, D_{\mathrm{x}}=1.247 \mathrm{~g}$ $\mathrm{cm}^{-3}, \mu=3.176 \mathrm{~mm}^{-1}, T_{\min }-T_{\max }: 0.445-0.619 .72524$ Reflections were measured up to a resolution of $(\sin \theta / \lambda)_{\max }=0.62 \AA^{-1} .22105$ Reflections were unique $\left(R_{\mathrm{int}}=0.0242\right)$, of which 20831 were observed $[I>2 \sigma(I)] .1549$ Parameters were refined using 987 restraints. $R 1 / w R 2[I>2 \sigma(I)]: 0.0500 / 0.1381 . R 1 / w R 2$ [all refl.]: 0.0524/0.1403. S $=1.036$. Residual

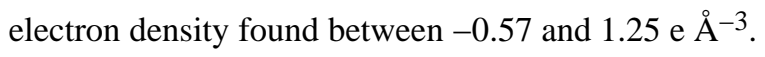


Photocatalytic Reactivity-The catalytic reactivity of $\mathrm{Mn}^{\mathrm{III}}\left(\mathrm{TBP}_{8} \mathrm{Cz}\right)\left(1.0 \times 10^{-5} \mathrm{M}\right)$ was examined under a large excess of a substrate (hexamethylbenzene or thioanisole: $0-0.3$ $\mathrm{M})$ in the presence of HOTf $\left(0-1.0 \times 10^{-4} \mathrm{M}\right)$ in PhCN $(2.0 \mathrm{~mL})$. This solution was transferred to a glass cuvette equipped with a stir bar. The generated products of the reaction solution were analyzed by GC-MS. An aliquot was taken from the product solution and injected directly into the GC-MS for analysis. All peaks of interest were identified by comparison of retention times and co-injection with authentic samples. The amounts of products were quantified by comparison against a known amount of detected products using a calibration curve consisting of a plot of product mole versus area. Mass spectra were recorded on a JEOL JMS-700T Tandem MS station, and the GC-MS analyses were carried out by using a Shimadzu GCMS-QP2000 gas chromatograph mass spectrometer. GC-MS conditions in these experiments were performed as follows: an initial oven temperature of $60{ }^{\circ} \mathrm{C}$ was held for $1 \mathrm{~min}$ and then raised $30^{\circ} \mathrm{C} \mathrm{min}-1$ for 7.3 min until a temperature of $250{ }^{\circ} \mathrm{C}$ was reached, which was then held for further $10 \mathrm{~min}$. The products pentamethylbenzyl alcohol and pentamethylbenzaldehyde were identified by comparison with a standard sample. The product yields were quantified by comparison against a known amount of detected products using a calibration curve consisting of a plot of product mole versus area. Calibration curves were prepared by using concentrations in the same range as that observed in the actual reaction mixtures.

Quantum Yield Determination-A standard actinometer (potassium ferrioxalate) ${ }^{50}$ was used for the quantum yield determination of photocatalytic oxidation of $\mathrm{HMB}$ by $\mathrm{O}_{2}$ with $\mathrm{Mn}^{\mathrm{III}}\left(\mathrm{TBP}_{8} \mathrm{Cz}\right)$ in $\mathrm{O}_{2}$-saturated PhCN. Typically, a square quartz cuvette $(10 \mathrm{~mm}$ i.d.), which contained an $\mathrm{O}_{2}$-saturated $\mathrm{PhCN}$ solution $(2.0 \mathrm{~mL})$ of $\mathrm{Mn}^{\mathrm{III}}\left(\mathrm{TBP}_{8} \mathrm{Cz}\right)\left(1.0 \times 10^{-5} \mathrm{M}\right)$ and HMB $(0.4 \mathrm{M})$ in the presence of HOTf $\left(4.0 \times 10^{-5} \mathrm{M}\right)$ was irradiated with monochromatic light of $\lambda=450 \mathrm{~nm}$ from a Shimadzu RF-5300PC fluorescence spectrophotometer. Under the conditions of actinometry experiments, the actinometer and $\mathrm{Mn}^{\mathrm{III}}\left(\mathrm{TBP}_{8} \mathrm{Cz}\right)$ absorbed essentially all of the incident light at $\lambda=450 \mathrm{~nm}$. The light intensity of monochromatized light at $\lambda=450 \mathrm{~nm}$ was determined to be $3.7 \times 10^{-8}$ einstein $\mathrm{s}^{-1}$. The quantum yields were determined by the amount of generated a product.

Femtosecond Laser Flash Photolysis Measurements-Measurements of transient absorption spectra of $\mathrm{Mn}^{\mathrm{III}}(\mathrm{OTf})\left(\mathrm{TBP}_{8} \mathrm{Cz}(\mathrm{H})\right)$ and $\left[\mathrm{Mn}^{\mathrm{III}}(\mathrm{OTf})\left(\mathrm{H}_{2} \mathrm{O}\right)\left(\mathrm{TBP}_{8} \mathrm{Cz}(\mathrm{H})_{2}\right)\right][\mathrm{OTf}]$ were performed according to the following procedures. An $\mathrm{N}_{2}$ - or $\mathrm{O}_{2}$-saturated $\mathrm{PhCN}$ solution containing $\mathrm{Mn}^{\mathrm{III}}\left(\mathrm{TBP}_{8} \mathrm{Cz}\right)\left(8.4 \times 10^{-5} \mathrm{M}\right)$ and $\operatorname{HOTf}\left(1.7 \times 10^{-4}\right.$ or $\left.1.2 \times 10^{-2} \mathrm{M}\right)$ was excited using an ultrafast source, Integra-C (Quantronix Corp.), an optical parametric amplifier, TOPAS (Light Conversion Ltd.), and a commercially available optical detection system, Helios provided by Ultrafast Systems LLC. The source for the pump and probe pulses were derived from the fundamental output of Integra-C $(\lambda=786 \mathrm{~nm}, 2 \mathrm{~mJ} / \mathrm{pulse}$ and fwhm $=130 \mathrm{fs}$ ) at a repetition rate of $1 \mathrm{kHz} .75 \%$ of the fundamental output of the laser was introduced into a second harmonic generation (SHG) unit: Apollo (Ultrafast Systems) for excitation light generation at $\lambda=393 \mathrm{~nm}$, while the rest of the output was used for white light generation. The laser pulse was focused on a sapphire plate of $3 \mathrm{~mm}$ thickness and then white light continuum covering the visible region from $\lambda=410 \mathrm{~nm}$ to $800 \mathrm{~nm}$ was generated via self-phase modulation. A variable neutral density filter, an optical aperture, and a pair of 
polarizer were inserted in the path in order to generate stable white light continuum. Prior to generating the probe continuum, the laser pulse was fed to a delay line that provides an experimental time window of $3.2 \mathrm{~ns}$ with a maximum step resolution of $7 \mathrm{fs}$. In our experiments, a wavelength at $\lambda=393 \mathrm{~nm}$ of SHG output was irradiated at the sample cell with a spot size of $1 \mathrm{~mm}$ diameter where it was merged with the white probe pulse in a close angle $\left(<10^{\circ}\right)$. The probe beam after passing through the $2 \mathrm{~mm}$ sample cell was focused on a fiber optic cable that was connected to a CMOS spectrograph for recording the timeresolved spectra $(\lambda=410-800 \mathrm{~nm})$. Typically, 1500 excitation pulses were averaged for 3 seconds to obtain the transient spectrum at a set delay time. Kinetic traces at appropriate wavelengths were assembled from the time-resolved spectral data. The decay rate of the tripquintet $\left({ }^{5} \mathrm{~T}_{1}\right)$ obeyed the first-order kinetics given by eq 1 ,

$$
\Delta \mathrm{Abs}=A_{1} \exp \left(-k_{1} t\right)+A_{2}
$$

where $A_{1}$ and $A_{2}$ are pre-exponential factors for the absorbance changes and the final absorbance, and $k_{1}$ is the rate constant of the decay of the tripquintet $\left({ }^{5} \mathrm{~T}_{1}\right)$ after irradiation. The slower decay rate of the tripseptet $\left({ }^{7} \mathrm{~T}_{1}\right)$ also obeyed the first-order kinetics given by eq 2, where $A_{3}$ is the final absorbance of ${ }^{7} \mathrm{~T}_{1}$ and $k_{2}$ is the rate constant of the decay of ${ }^{7} \mathrm{~T}_{1}$. All measurements were conducted at room temperature, $298 \mathrm{~K}$.

$$
\Delta \mathrm{Abs}=A_{1} \exp \left(-k_{1} t\right)+A_{2} \exp \left(-k_{2} t\right)+A_{3}
$$

\section{RESULTS AND DISCUSSION}

\section{Protonation of $\mathrm{Mn}^{\mathrm{III}}\left(\mathrm{TBP}_{8} \mathrm{Cz}\right)$}

Protonation of $\mathrm{Mn}^{\mathrm{III}}\left(\mathrm{TBP}_{8} \mathrm{Cz}\right)$ was examined by addition of HOTf to a PhCN solution of $\mathrm{Mn}^{\mathrm{III}}\left(\mathrm{TBP}_{8} \mathrm{Cz}\right)\left(1.0 \times 10^{-5} \mathrm{M}\right)$. The formation of a new species with a Q-band at $\lambda_{\max }=725$ $\mathrm{nm}$, was monitored by UV-vis as shown in Figure 1a, where HOTf was added up to 1 equiv of $\mathrm{Mn}^{\mathrm{III}}\left(\mathrm{TBP}_{8} \mathrm{Cz}\right)$. A color change from brown to reddish-brown was observed. This spectral change was similar to that seen for the addition of 1 equiv of $\mathrm{H}^{+}\left[\mathrm{B}\left(\mathrm{C}_{6} \mathrm{~F}_{5}\right)_{4}\right]^{-}$, and indicated the formation of the monoprotonated complex, $\mathrm{Mn}^{\mathrm{III}}(\mathrm{OTf})\left(\mathrm{TBP}_{8} \mathrm{Cz}(\mathrm{H})\right)(\mathbf{1})$. Addition of excess HOTf $\left(1.0 \times 10^{-5}-1.0 \times 10^{-2} \mathrm{M}\right)$ resulted in a change in the Q-band region to give $\lambda_{\max }=745 \mathrm{~nm}$ with the isosbestic points as shown in Figure 2. These data were consistent with the formation of the diprotonated, $\left[\mathrm{Mn}^{\mathrm{III}}(\mathrm{OTf})\left(\mathrm{TBP}_{8} \mathrm{Cz}(\mathrm{H})_{2}\right)\right]-[\mathrm{OTf}]$ (2) and again similar to the spectral changes observed for $\mathrm{H}^{+}\left[\mathrm{B}\left(\mathrm{C}_{6} \mathrm{~F}_{5}\right)_{4}\right]^{-}$.

The monoprotonation equilibrium constant $\left(K_{1}\right)$ for $\mathbf{1}$ was determined by fitting of the titration curves in Figure 1b, according to the equilibrium expression in eq 3. This analysis gave

$$
\mathrm{Mn}^{\mathrm{III}}\left(\mathrm{TBP}_{8} \mathrm{Cz}\right)+\mathrm{H}^{+}+\mathrm{OTf}^{-} \stackrel{K_{1}}{\rightleftharpoons} \mathrm{Mn}^{\mathrm{III}}(\mathrm{OTf})\left(\mathrm{TBP}_{8} \mathrm{Cz}(\mathrm{H})\right)
$$


$K_{1}=9.0 \times 10^{6} \mathrm{M}^{-1}$, indicating strong binding of $\mathrm{H}^{+}$to $\mathrm{Mn}^{\mathrm{III}}\left(\mathrm{TBP}_{8} \mathrm{Cz}\right)$. The second equilibrium constant $\left(K_{2}\right)$ for the protonation equilibrium in eq 4 , was determined to be 4.7 $\times 10^{3} \mathrm{M}^{-1}$ by

$\mathrm{Mn}^{\mathrm{III}}(\mathrm{OTf})\left(\mathrm{TBP}_{8} \mathrm{Cz}(\mathrm{H})\right)+\mathrm{H}^{+}+\mathrm{OTf}^{-} \stackrel{K_{2}}{\rightleftharpoons}\left[\mathrm{Mn}^{\mathrm{III}}(\mathrm{OTf})\left(\mathrm{H}_{2} \mathrm{O}\right)\left(\mathrm{TBP}_{8} \mathrm{Cz}(\mathrm{H})_{2}\right)\right][\mathrm{OTf}]$

fitting a plot of reciprocal absorbance difference vs 1/[HOTf] from the titration curve in Figure $2 \mathrm{~b}$ (see Figure $\mathrm{S} 1$ in the Supporting Information (SI)). The $K_{1}$ value for the first protonation to give $\mathbf{1}$ is much larger than the $K_{2}$ value for the second species $\mathbf{2}$.

The protonated complexes $\mathbf{1}$ and $\mathbf{2}$ were successfully crystallized and characterized by single crystal X-ray Diffraction (XRD) (Figure 3). The monoprotonated complex was originally crystallized from reaction of $\mathrm{Mn}^{\mathrm{III}}\left(\mathrm{TBP}_{8} \mathrm{Cz}\right)$ with 10 equiv $\mathrm{Sc}(\mathrm{OTf})_{3}$ in $\mathrm{CH}_{2} \mathrm{Cl}_{2} / \mathrm{CH}_{3} \mathrm{CN}$. The strongly Lewis acidic $\mathrm{Sc}^{3+}$ ion presumably reacts with exogenous $\mathrm{H}_{2} \mathrm{O}$ to generate the proton source, and slow evaporation produced X-ray quality crystals of $\mathbf{1}$ after 4 weeks. The crystal structure revealed that monoprotonation occurs at one of the meso-N-atoms $(\mathrm{N} 5(\mathrm{H}))$ adjacent to the direct pyrrole-pyrrole bond of the corrolazine ligand, and that the manganese center is five-coordinate with an axially-ligated triflate $\left(\mathrm{Mn}_{-}^{\mathrm{III}}-\mathrm{O}=2.115(3) \AA\right)$. The same crystals were subsequently obtained from reaction o $\mathrm{Mn}^{\mathrm{III}}\left(\mathrm{TBP}_{8} \mathrm{Cz}\right)$ with 1 equiv HOTF and recrystallization from $\mathrm{CH}_{2} \mathrm{Cl}_{2}$ /heptane. A unit cell measurement matched that for $\mathbf{1}$.

Dissolution of crystalline 1 in PhCN yields the same UV-vis spectrum as seen for the in situ protonation o $\mathrm{Mn}^{\mathrm{III}}\left(\mathrm{TBP}_{8} \mathrm{Cz}\right)$ by the addition of 1 equiv of $\mathrm{HOTF}\left(\lambda_{\max }=451,725 \mathrm{~nm}\right)$ (Figure S2). Interestingly dissolution of crystalline $\mathbf{1}$ in $\mathrm{CH}_{2} \mathrm{Cl}_{2}$ (Figure S3) gives a UV-vis spectrum with $\lambda_{\max }=443,725 \mathrm{~nm}$, similar to what was seen for $\left[\mathrm{Mn}^{\mathrm{III}}\left(\mathrm{H}_{2} \mathrm{O}\right)\left(\mathrm{TBP}_{8} \mathrm{Cz}(\mathrm{H})\right)\right]$ $\left[\mathrm{B}\left(\mathrm{C}_{6} \mathrm{~F}_{5}\right)_{4}\right]\left(\lambda_{\max }=446,730 \mathrm{~nm} \text { in } \mathrm{CH}_{2} \mathrm{Cl}_{2}\right)^{43}$ although the Q-band is shifted by $5 \mathrm{~nm}$. A similar red-shift in the Q-band occurs upon axial ligation of anionic donors to $\mathrm{Mn}^{\mathrm{III}}\left(\mathrm{H}_{2} \mathrm{O}\right)$ $\left(\mathrm{TBP}_{8} \mathrm{Cz}\right)$ to give $\left[\mathrm{Mn}^{\mathrm{III}}(\mathrm{X})\left(\mathrm{TBP}_{8} \mathrm{Cz}\right)\right]^{-}\left(\text {e.g. } \mathrm{X}=\mathrm{CN}^{-}, \mathrm{F}^{-}\right)^{51}$.

$\mathrm{X}$-ray quality crystals of the diprotonated complex 2 were obtained from the reaction of $\mathrm{Mn}^{\mathrm{III}}\left(\mathrm{TBP}_{8} \mathrm{Cz}\right.$ ) with 2 equiv HOTf and recrystallization from $\mathrm{CH}_{2} \mathrm{Cl}_{2}$ /heptanes (Figure 3). Both $\mathrm{H}$-atoms were unambiguously located on the opposite meso-N atoms (N1 and N5). In contrast to the monoprotonated complex, the diprotonated complex has a six coordinate manganese center with an axially ligated water at 2.144(2) $\AA$ and a weakly bound triflate at 2.702(2) ̊.

Dissolution of crystalline 2 in $\mathrm{CH}_{2} \mathrm{Cl}_{2}$ yielded a spectrum with $\lambda_{\max }$ at 454 and $758 \mathrm{~nm}$ (Figure S4). Comparing this spectrum to that seen for the diprotonated $\left[\mathrm{Mn}^{\mathrm{III}}\left(\mathrm{H}_{2} \mathrm{O}\right)\right.$ $\left.\left(\mathrm{TBP}_{8} \mathrm{Cz}(\mathrm{H})_{2}\right)\right]-\left[\mathrm{B}\left(\mathrm{C}_{6} \mathrm{~F}_{5}\right)_{4}\right]_{2}\left(\lambda_{\max }: 470,763\right)^{43}$ in the same solvent again reveals a red-shift of $5 \mathrm{~nm}$ in the Q-band, matching the differences seen for the two monoprotonated spectra. These results indicate that the triflate (-OTf) anion stays bound in solution for both the mono- and diprotonated complexes. When crystalline 2 was dissolved in $\mathrm{PhCN}$, the UV-vis spectrum matched that for the monoprotonated complex, indicating that this solvent is basic enough to deprotonate the second meso- $\mathrm{N}$ atom. 


\section{Photocatalytic Oxygenations with $\mathrm{O}_{2}$ by $\mathrm{Mn}^{\mathrm{III}}\left(\mathrm{TBP}_{8} \mathrm{Cz}\right)$ in the Presence of HOTf}

Previously it was shown that the addition of $\mathrm{H}^{+}\left[\mathrm{B}\left(\mathrm{C}_{6} \mathrm{~F}_{5}\right)_{4}\right]^{-}$to $\mathrm{Mn}^{\mathrm{III}}\left(\mathrm{TBP}_{8} \mathrm{Cz}\right)$ allowed for photo-activated catalysis of $\mathrm{HMB}$ under ambient conditions, but only with modest turnover numbers and selectivity. ${ }^{43}$ Replacement of $\mathrm{H}^{+}\left[\mathrm{B}\left(\mathrm{C}_{6} \mathrm{~F}_{5}\right)_{4}\right]^{-}$with the strong acid HOTf led to the photocatalytic oxygenation of $\mathrm{HMB}$ by $\mathrm{O}_{2}$ and $\mathrm{Mn}^{\mathrm{III}}\left(\mathrm{TBP}_{8} \mathrm{Cz}\right)$ in $\mathrm{PhCN}$.

The addition of HOTf (2 equiv) to $\mathrm{Mn}^{\mathrm{III}}\left(\mathrm{TBP}_{8} \mathrm{Cz}\right)$ in $\mathrm{PhCN}$ gave a spectrum $\left(\lambda_{\max }=451\right.$, $725 \mathrm{~nm}$ ) indicative of $\mathbf{1}$. Addition of HMB followed by photoirradiation initiated the catalytic reaction, which occured over $6 \mathrm{~h}$ with slow bleaching of the solution (Figure S5 in SI). Regarding the bleaching of the catalyst, we followed the reaction by UV-vis, which showed only the slow loss of the ground state complex. The catalytically active excited state was only present to a small extent at any time, and therefore the slow decomposition of the ground state (which is in large excess) did not change the effective concentration of the catalytically active excited state to a large extent. Analysis of the reaction mixture by removal of aliquots and analysis by GC showed a steady increase in the amount of oxidized products produced over time. Thus, there is an optimized concentration of HOTf for the phtoocatalytic oxygenation of $\mathrm{HMB}$ by $\mathrm{O}_{2}$ with 1 . The reason why the photocatlaytic oxygenation is prohibited in the presence of large concentrations of HOTf is discussed in relation with the phtoocatalytic reaction mechanism (vide infra). The production of oxidized products seemed only limited by the catalyst stability. The final turnover number (TON) was 563 for the alcohol PMB-OH and 9 for the aldehyde PMB- CHO (Figure S6 in SI), with a quantum yield of $0.125 \%$. The catalytic turnover is dramatically increased by HOTf in comparison to $\mathrm{H}^{+}\left[\mathrm{B}\left(\mathrm{C}_{6} \mathrm{~F}_{5}\right)_{4}\right]^{-}$, which gave only TON $(\mathrm{PMB}-\mathrm{OH})=18$ and TON(PMB$\mathrm{CHO})=9 .{ }^{43}$ In addition, the HOTf reaction is much more selective for production of the alcohol product. When the HMB was replaced by dueturated HMB, the reactivity was lower. The kinetic isotope effect (KIE) was determined to be 3.3 with linear increase of PMB-OH vs time, indicating $\mathrm{H}$-atom abstraction is the rate determining step in the overall photocatalytic reaction.

The amount of $\mathrm{PMB}-\mathrm{OH}$ produced after $1 \mathrm{~h}$ photoirradiation of a $\mathrm{PhCN}$ solution of $\mathrm{Mn}^{\mathrm{III}}\left(\mathrm{TBP}_{8} \mathrm{Cz}\right)$ with $\mathrm{HMB}, \mathrm{O}_{2}$ and HOTf was proportional to concentrations of $\mathrm{HMB}$ (Figure $4 \mathrm{a}$ ) and $\mathrm{O}_{2}$ (Figure $4 \mathrm{~b}$ ). Thus, the rate-determining step in the photocatalytic oxygenation of $\mathrm{HMB}$ by $\mathrm{O}_{2}$ may be the reaction of the photogenerated species from 1 with $\mathrm{O}_{2}$ and HMB. If HOTf is added in excess (10 equiv), $\mathbf{2}$ is formed as seen by UV-vis. Photoirradiation of this complex in the presence of $\mathrm{HMB} / \mathrm{O}_{2}$ shows no oxidized products. This result is consistent with previous observations on the diprotonated $\mathrm{Mn}^{\mathrm{III}}$ complex generated from $\mathrm{H}^{+}\left[\mathrm{B}\left(\mathrm{C}_{6} \mathrm{~F}_{5}\right)_{4}\right]^{-}$, which also showed no catalytical activity. ${ }^{43}$ The amount of $\mathrm{PMB}-\mathrm{OH}$ produced by 30 min photoirradiation with a Xenon lamp increased with increasing concentration of HOTf to reach a maximum and then decreased with further increase in concentrationof HOTf as shown in Figure 5 because of the formation of the diprotonated complex 2 which shows no catalytic activity for oxygenation of $\mathrm{HMB}$ by $\mathrm{O}_{2}$ in the presence of large excess HOTf (Figure S6b). 


\section{Photocatalytic Sulfoxidation by $\mathrm{Mn}^{\mathrm{III}}\left(\mathrm{TBP}_{8} \mathrm{Cz}\right)$ in the Presence of HOTf}

In our previous studies we focused exclusively on $\mathrm{C}-\mathrm{H}$ functionalization with toluene derivatives. In the current work we wanted to determine if photocataytic oxygenation could be obtained with an O-atom acceptor substrate, and the thioether substrate PhSMe was examined. There have been some reports involving iron complexes reacting with $\mathrm{O}_{2}$ to give catalytic sulfoxidation of thioether substrates, although they often involved poorly controlled radical-type pathways. ${ }^{52}$ The photoactivation of diiron(III)- $\mu$-oxo-bridged porphyrins has also lead to catalytic sulfoxidation where dioxygen is used to regenerate the $\mu$-oxo complex. ${ }^{53}$ Dioxygen has been utilized by iron complexes for catalytic sulfoxidation by the formation of a peracid oxidant. ${ }^{54}$ However, there remains few examples of sulfoxidation mediated by $\mathrm{O}_{2}$ and well-defined transition metal catalysts that avoid co-additives or radicaltype pathways. When HMB was replaced by thioanisole in the photocatalytic reaction with $\mathrm{Mn}^{\mathrm{III}}(\mathrm{OTf})\left(\mathrm{TBP}_{8} \mathrm{Cz}(\mathrm{H})\right)$, a single S-oxygenated product, methylphenylsulfoxide $(\mathrm{PhS}(\mathrm{O}) \mathrm{Me})$, was obtained (Scheme 2). Excellent TONs (902) and conversion (98\%) of $\mathrm{PhSMe}$ to $\mathrm{PhS}(\mathrm{O}) \mathrm{Me}$ was found (Figure S7a) whereas negligible amount of $\mathrm{PhS}(\mathrm{O}) \mathrm{Me}$ (TON: 14) was obtained in the absence of HOTf (Figure S7b). Control experiments confirmed that no corresponding products were observed without photoirradiation or without the $\mathrm{Mn}^{\mathrm{III}}$ complex (see Figure S8 in SI). These results show that $\mathrm{Mn}^{\mathrm{III}}\left(\mathrm{TBP}_{8} \mathrm{Cz}\right.$ ) is an efficient and selective catalyst for the sulfoxidation of thioanisole, and requires only air, light, and an $\mathrm{H}^{+}$source without the need for a co-reductant.

\section{Femtosecond Transient Absorption Measurements}

In order to clarify the photodynamics of $\mathbf{1}$ and $\mathbf{2}$, femtosecond laser flash photolysis measurements were performed in the absence and presence of $\mathrm{O}_{2}$ in $\mathrm{PhCN}$. The $\mathrm{Mn}^{\mathrm{III}}$ ion is a high spin $(S=2)$ species, and coupling between the metal $d$ electrons and the $\pi$ electrons of the corrolazine ring leads to a singquintet $\left({ }^{5} \mathrm{~S}_{0}\right)$ ground state derived from the lowest excited ring $\left(\pi, \pi^{*}\right)$ singlet for $\mathbf{1}$ and $\mathbf{2}$ due to the coupling between unpaired electrons of the metal with the $\pi$ electrons of the corrolazine ring. A "tripmultiplet" manifold $\left({ }^{3} \mathrm{~T}_{1},{ }^{5} \mathrm{~T}_{1},{ }^{7} \mathrm{~T}_{1}\right)$ is derived from the lowest ring $\left(\pi, \pi^{*}\right)$ triplet. $^{55}$ Femtosecond laser excitation of $\mathbf{1}$ leads to a new maximum absorption at $610 \mathrm{~nm}$, which can be assigned to the tripquintet $\left({ }^{5} \mathrm{~T}_{1}\right)$ excited state (Figure 6). The absorption due to the tripquintet $\left({ }^{5} \mathrm{~T}_{1}\right)$ decayed in a few ps with a rate constant of $3.1 \times 10^{9} \mathrm{~s}^{-1}$, and there was no effect of $\mathrm{O}_{2}$ on the rate due to the fast intersystem crossing to the tripseptet excited state $\left({ }^{7} \mathrm{~T}_{1}\right)$ of $\mathbf{1}$ with a longer lifetime (Figure 6). An extremely rapid intersystem crossing process from the singquintet excited state $\left({ }^{5} S_{1}\right)$ to the tripquintet excited state $\left({ }^{5} \mathrm{~T}_{1}\right)$ resulting from the presence of unpaired electrons has been seen for a first row paramagnetic complex, $\mathrm{Mn}^{\mathrm{III}} .{ }^{56}$ For example, in $\mathrm{Mn}^{\mathrm{III}}$ porphyrins, the existence of two tripmultiplet levels was suggested where a tripquintet $\left({ }^{5} \mathrm{~T}_{1}\right)$ relaxes to a long-lived tripseptet $\left({ }^{7} \mathrm{~T}_{1}\right)$, which requires a spin conversion to go back to the quintet ground state. The absorption at $610 \mathrm{~nm}$ due to the tripseptet excited state $\left({ }^{7} \mathrm{~T}_{1}\right)$ decayed significantly faster in $\mathrm{O}_{2}$-saturated $\mathrm{PhCN}$ (Figure 6c) as compared with the decay in the absence of $\mathrm{O}_{2}$ (Figure 6b). The rate constant of the reaction of ${ }^{7} \mathrm{~T}_{1}$ of 1 with $\mathrm{O}_{2}$ was determined to be $5.0 \times$ $10^{9} \mathrm{M}^{-1} \mathrm{~s}^{-1}$, which is the same as that of the reaction of ${ }^{7} \mathrm{~T}_{1}$ of neutral $\mathrm{Mn}^{\mathrm{III}}\left(\mathrm{TBP}_{8} \mathrm{Cz}\right)$ with $\mathrm{O}_{2}{ }^{16}$ This reaction should produce the putative superoxo complex $\left(\left[\mathrm{Mn}^{\mathrm{IV}}\left(\mathrm{O}_{2}{ }^{-}\right)\right.\right.$ $\left.\left.\left(\mathrm{TBP}_{8} \mathrm{Cz}(\mathrm{H})\right)\right]^{+}\right)$. 
Femtosecond laser flash photolysis measurements of $\mathbf{2}$ were also performed to characterize the excited state of the diprotonated species in the absence and presence of $\mathrm{O}_{2}$ in $\mathrm{PhCN}$, as shown in Figure 7. The decay rate constant of the intersystem crossing from the tripquintet excited state $\left({ }^{5} \mathrm{~T}_{1}\right)$ to the tripseptet excited state $\left({ }^{7} \mathrm{~T}_{1}\right)$ was determined to be $9.4 \times 10^{9} \mathrm{~s}^{-1}$ at $745 \mathrm{~nm}$ in both the absence and presence of $\mathrm{O}_{2}$. In contrast to the case of $\mathrm{Mn}^{\mathrm{III}}\left(\mathrm{TBP}_{8} \mathrm{Cz}\right)$ and $\mathbf{1}$, the decay rate constant for the tripseptet excited state $\left({ }^{7} \mathrm{~T}_{1}\right)$ of $\mathbf{2}$ was slower $\left(2.2 \times 10^{9}\right.$ $\mathrm{s}^{-1}$ at $\left.745 \mathrm{~nm}\right)$ and showed no $\mathrm{O}_{2}$ dependence. Thus, the tripseptet excited state $\left({ }^{7} \mathrm{~T}_{1}\right)$ of $\mathbf{2}$ does not react with $\mathrm{O}_{2}$, in line with the observation that $\mathbf{2}$ is not catalytically active. We hypothesize that the one electron oxidation potential of ${ }^{7} \mathrm{~T}_{1}$ of $\mathbf{2}$ may be too high for reaction with $\mathrm{O}_{2}$.

\section{Oxidation Potentials of $\mathrm{Mn}^{\mathrm{III}}\left(\mathrm{TBP}_{8} \mathrm{Cz}\right), \mathrm{Mn}^{\mathrm{III}}(\mathrm{OTf})\left(\mathrm{TBP}_{8} \mathrm{Cz}(\mathrm{H})\right)$ and [Mn ${ }^{\mathrm{III}}(\mathrm{OTf})-\left(\mathrm{H}_{2} \mathrm{O}\right)$ $\left.\left(\mathrm{TBP}_{8} \mathrm{Cz}(\mathrm{H})_{2}\right)\right][\mathrm{OTf}]$}

The effects of protonation of $\mathrm{Mn}^{\mathrm{III}}\left(\mathrm{TBP}_{8} \mathrm{Cz}\right)$ on the one-electron oxidation potentials were examined by cyclic voltammetry measurements of $\mathrm{Mn}^{\mathrm{III}}\left(\mathrm{TBP}_{8} \mathrm{Cz}\right), \mathbf{1}$, and $\mathbf{2}$, and the peak potentials (referenced to SCE) are shown in Figure 8. The first one-electron oxidation potential of $\mathrm{Mn}^{\mathrm{III}}\left(\mathrm{TBP}_{8} \mathrm{Cz}\right)$ was determined to be $E_{\mathrm{OX}}=0.78 \mathrm{~V}$ vs SCE in $\mathrm{PhCN}$, which was shifted to the positive direction by the addition of HOTf: $E_{\mathrm{OX}}=1.04 \mathrm{~V}$ for $\mathbf{1}$ and $E_{\mathrm{OX}}=1.36$ $\mathrm{V}$ for $\mathbf{2}$. However, the second one-electron oxidation potential was not positively shifted by the addition of HOTf: $E_{\mathrm{Ox}}=1.23 \mathrm{~V}$ for $\mathrm{Mn}^{\mathrm{III}}\left(\mathrm{TBP}_{8} \mathrm{Cz}\right)$ and $E_{\mathrm{Ox}}=1.20 \mathrm{~V}$ for 1 probably because of the counter anion effect of OTf ${ }^{-}$. Although the energies of ${ }^{7} \mathrm{~T}_{1}$ of $\mathrm{Mn}^{\mathrm{III}}\left(\mathrm{TBP}_{8} \mathrm{Cz}\right)$, 1 and $\mathbf{2}$ have yet to be determined because of the absence of phosphorescence, the $E_{\mathrm{OX}}$ value of $\mathbf{2}$ in the ground state, which is $0.32 \mathrm{~V}$ higher than that of $\mathbf{1}$, is consistent with the observation that the ${ }^{7} \mathrm{~T}_{1}$ of $\mathbf{2}$ is unreactive towards $\mathrm{O}_{2}$ in contrast to $\mathbf{1}$.

\section{Reaction Mechanism}

Based on the study of the photocatalytic oxygenation of $\mathrm{HMB}$ by $\mathrm{O}_{2}$ with $\mathbf{1}$ and photodynamics of $\mathbf{1}$ (vide supra), the mechanism of photocatalytic oxygenation of HMB by $\mathrm{O}_{2}$ with $\mathbf{1}$ is proposed as shown in Scheme 3.

In the presence of 1 equiv of HOTf, $\mathrm{Mn}^{\mathrm{III}}\left(\mathrm{TBP}_{8} \mathrm{Cz}\right)$ is converted to the monoprotonated complex 1, which is then excited to the tripquintet state $\left\{\mathrm{Mn}^{\mathrm{III}}(\mathrm{OTf})\left(\mathrm{TBP}_{8} \mathrm{Cz}(\mathrm{H})\right)\right\}^{*}\left({ }^{5} \mathrm{~T}_{1}\right)$ upon photoirradiation. The ${ }^{5} \mathrm{~T}_{1}$ of $\mathbf{1}$ is converted rapidly by intersystem crossing (ISC) to the tripseptet excited state $\left({ }^{7} \mathrm{~T}_{1}\right)$. Electron transfer from ${ }^{7} \mathrm{~T}_{1}$ to $\mathrm{O}_{2}$ occurs to produce the superoxo complex $\left[\mathrm{Mn}^{\mathrm{IV}}\left(\mathrm{O}_{2}{ }^{--}\right)(\mathrm{OTf})\left(\mathrm{TBP}_{8} \mathrm{Cz}(\mathrm{H})\right)\right]$, which abstracts a hydrogen atom from $\mathrm{HMB}$ to produce the hydroperoxo complex $\left[\mathrm{Mn}^{\mathrm{IV}}(\mathrm{OOH})(\mathrm{OTf})\left(\mathrm{TBP}_{8} \mathrm{Cz}(\mathrm{H})\right)\right]$ and pentamethylbenzyl radical, in competition with the back electron-transfer $\left(k_{-\mathrm{et}}\right)$ to regenerate the ground state $\mathbf{1}$ and $\mathrm{O}_{2}$. $\mathrm{C}-\mathrm{H}$ activation by a metal superoxo species has been demonstrated with chromium and copper non-heme model complexes. ${ }^{57}$ In our case, the subsequent homolytic $\mathrm{O}-\mathrm{O}$ bond cleavage and combination with benzyl radical to yield PMB-OH is accompanied by generation of high-valent $\mathrm{Mn}^{\mathrm{V}}(\mathrm{O})(\mathrm{OTf})\left(\mathrm{TBP}_{8} \mathrm{Cz}(\mathrm{H})\right)$, followed by conversion to $\mathrm{Mn}^{\mathrm{IV}}(\mathrm{OH})(\mathrm{OTf})\left(\mathrm{TBP}_{8} \mathrm{Cz}^{*+}\right) .{ }^{43}$ This species, in the presence of excess $\mathrm{H}^{+}$, is proposed to react with another equivalent of substrate to produce $\mathrm{PMB}-\mathrm{OH}$, regenerate $\mathbf{1}$, and close the catalytic cycle. 
When $\mathbf{1}$ is further protonated to $\mathbf{2}$ in the presence of a large excess of HOTf no catalytic activity is observed. The tripseptet excited state $\left({ }^{7} \mathrm{~T}_{1}\right)$ of $\mathbf{2}$ is favored to go back to the ground state rather than react with $\mathrm{O}_{2}$, possibly due to the higher oxidation potential for $\mathbf{2}$ as compared with that of $\mathbf{1}$ (vide supra) as shown in Scheme 4. As a result, the photocatalytic oxygenation of $\mathrm{HMB}$ by $\mathrm{O}_{2}$ with $\mathrm{Mn}^{\mathrm{III}}\left(\mathrm{TBP}_{8} \mathrm{Cz}\right)$ does not occur in the presence of large excess HOTf (10 equiv HOTf). In such a case, the involvement of singlet oxygen is unlikely, because the formation of singlet oxygen may not be affected by the acid. In addition, the efficient photocatalytic oxygenation of thioanisole by $\mathrm{O}_{2}$ with $\mathrm{Mn}^{\mathrm{III}}\left(\mathrm{TBP}_{8} \mathrm{Cz}\right)$ and HOTf in $\mathrm{PhCN}$ (Scheme 2) also suggests no involvment of singlet oxygen, because the reactions of alkyl and aryl sulfides with singlet oxygen in aprotic solvents such as PhCN is known to be sluggish. $^{58}$

\section{Protonation of $\mathrm{Mn}^{\mathrm{V}}(\mathrm{O})\left(\mathrm{TBP}_{8} \mathrm{Cz}\right)$}

To further study the proposed final step in the catalysis to regenerate the $\mathrm{Mn}^{\mathrm{III}}$ resting state, the reaction of isolated $\mathrm{Mn}^{\mathrm{V}}(\mathrm{O})\left(\mathrm{TBP}_{8} \mathrm{Cz}\right)$ with acid was studied. Protonation of $\mathrm{Mn}^{\mathrm{V}}(\mathrm{O})$ $\left(\mathrm{TBP}_{8} \mathrm{Cz}\right)$ was examined by reaction of $\mathrm{Mn}^{\mathrm{V}}(\mathrm{O})\left(\mathrm{TBP}_{8} \mathrm{Cz}\right)$ with HOTf in $\mathrm{PhCN}$ as shown in Figure 9a. The broadening and decrease in the intensity of the Soret band at $420 \mathrm{~nm}$ and the $\mathrm{Q}$ band at $634 \mathrm{~nm}$ together with the appearance of a relatively weak band in the near-IR region at $795 \mathrm{~nm}$ is characteristic of the formation of a porphyrinoid $\pi$-radical cation. ${ }^{43}$ The new spectrum matches that observed previously upon the addition of the Lewis or Brønsted acids $\left(\mathrm{Zn}^{\mathrm{II}}(\mathrm{OTf})_{2}, \mathrm{~B}\left(\mathrm{C}_{6} \mathrm{~F}_{5}\right)_{3}, \mathrm{H}^{+}\right)$to the $\mathrm{Mn}^{\mathrm{V}}(\mathrm{O})$ complex. ${ }^{42},{ }^{43}$ These acids stabilize a highspin triplet ( $S=1$ ) (or quintet $S=2$ ) state with an electronic configuration best described as a manganese(IV) corrolazine $\pi$-radical cation. ${ }^{42}$ Protonation of the terminal oxo ligand should weaken the $\mathrm{Mn}-\mathrm{O} \pi$-bonding and destabilize the $\mathrm{Mn}^{\mathrm{V}}$ oxidation state, favoring an $\mathrm{Mn}^{\mathrm{IV}}(\mathrm{O})\left(\pi\right.$-cation-radical) configuration. The formation of $\mathrm{Mn}^{\mathrm{IV}}(\mathrm{OH})(\mathrm{OTf})\left(\mathrm{TBP}_{8} \mathrm{Cz}^{\cdot+}\right)(\mathbf{3})$ $\left(\lambda_{\max }=795 \mathrm{~nm}\right)$ was monitored by UV-vis spectroscopy as shown in Figure 9, where HOTf was added up to 1 equiv. The equilibrium constant for the addition of acid to $\mathrm{Mn}^{\mathrm{V}}(\mathrm{O})$ $\left(\mathrm{TBP}_{8} \mathrm{Cz}\right)$ was determined to be $1.0 \times 10^{7} \mathrm{M}^{-1}$ by a plot of absorbance vs concentration of HOTf in Figure 9b. No further spectral changes were observed in the presence of large excess HOTf (Figure S9).

The addition of HMB to $\mathbf{3}$ and monitoring the reaction by UV-Vis showed slow decay of $\mathbf{3}$ and the growth of $\mathrm{Mn}^{\mathrm{III}}$ over 14 hours. In the presence of excess of HOTf, however, $\mathbf{3}$ is reduced by HMB to produce 1 (Figure S10b in SI) and PMB-OH (yield: 85\%) by GC-MS. Rates of the oxidation of $\mathrm{HMB}$ by $\mathrm{Mn}^{\mathrm{V}}(\mathrm{O})\left(\mathrm{TBP}_{8} \mathrm{Cz}\right)$ in the presence of excess HOTf were determined from an increase in absorbance at $725 \mathrm{~nm}$ due to $\mathbf{1}$ in a PhCN at $298 \mathrm{~K}$, obeying pseudo-first-order kinetics in the presence of large exess HMB and HOTf (Figure S11 and Figure S12 in SI). The observed pseudo-first-order rate constants are proportional to concentrations of HOTf and HMB to afford the second-order rate constants from the slopes of the linear plots as $1.4 \times 10^{-3} \mathrm{M}^{-1} \mathrm{~s}^{-1}$ (Figure 10a) and $5.3 \times 10^{-4} \mathrm{M}^{-1} \mathrm{~s}^{-1}$ (Figure 10b), respectively.

When HMB was replaced by mesitylene $\left(\mathrm{C}_{6} \mathrm{H}_{3}\left(\mathrm{CH}_{3}\right)_{3}\right), \mathbf{3}$ was also reduced by mesitylene in the presence of excess HOTf. A very small deuterium kinetic isotope effect (KIE) close to unity $(\mathrm{KIE}=1.1)$ was observed when $\mathrm{C}_{6} \mathrm{H}_{3}\left(\mathrm{CH}_{3}\right)_{3}$ was replaced by the deuterated 
compound $\left(\mathrm{C}_{6} \mathrm{D}_{3}\left(\mathrm{CD}_{3}\right)_{3}\right)$ as shown in Figure 11 . The KIE close to unity indicates that the oxidation of mesitylene as well as HMB by 3 proceeds via proton-coupled electron transfer from mesitylene and HMB to $\mathbf{3}$ rather than hydrogen atom transfer from mesitylene and HMB to 3 .

\section{CONCLUSIONS}

In conclusion, $\mathrm{Mn}^{\mathrm{III}}(\mathrm{OTf})\left(\mathrm{TBP}_{8} \mathrm{Cz}(\mathrm{H})\right)$ is capable of the photocatalytic oxygenation of $\mathrm{HMB}$ and $\mathrm{PhSMe}$ under ambient conditions, and was found to be a more robust, efficient and selective catalyst than the monoprotonated $\left[\mathrm{Mn}^{\mathrm{III}}\left(\mathrm{H}_{2} \mathrm{O}\right)(\mathrm{TBP} 8 \mathrm{Cz}(\mathrm{H}))\right]\left[\mathrm{B}\left(\mathrm{C}_{6} \mathrm{~F}_{5}\right)_{4}\right]$. Thus changing the acid from $\mathrm{H}^{+}\left[\mathrm{B}\left(\mathrm{C}_{6} \mathrm{~F}_{5}\right)_{4}\right]^{-}$to an acid with a different conjugate base resulted in a dramatic change in catalytic reactivity. The major difference in conjugate bases is the ability of $\mathrm{OTf}^{-}$to coordinate to the Mn center, and suggests that $\mathrm{OTf}^{-}$coordination has a significant influence on the catalytic activity of the system. The dynamics of the photoexcited states were similar for both acids, and the same photoexcited state mechanism can be invoked for both $\mathrm{H}^{+}\left[\mathrm{B}\left(\mathrm{C}_{6} \mathrm{~F}_{5}\right)_{4}\right]^{-}$and HOTf. The proton-coupled electron transfer from $\mathrm{HMB}$ to $\mathrm{Mn}^{\mathrm{IV}}(\mathrm{OH})(\mathrm{OTf})\left(\mathrm{TBP}_{8} \mathrm{Cz}^{\cdot+}\right)$ occurs to yield pentamethylbenzyl alcohol, accompanied by regeneration of $\mathrm{Mn}^{\mathrm{III}}(\mathrm{OTf})\left(\mathrm{TBP}_{8} \mathrm{Cz}(\mathrm{H})\right)$ to complete the catalytic cycle. The PCET oxidation of HMB by $\mathrm{Mn}^{\mathrm{IV}}(\mathrm{OH})(\mathrm{OTf})\left(\mathrm{TBP}_{8} \mathrm{Cz}^{-+}\right)$is enhanced with increasing concentration of HOTf. In the presence of large excess HOTf, however, $\mathrm{Mn}^{\mathrm{III}}(\mathrm{OTf})$ $\left(\mathrm{TBP}_{8} \mathrm{Cz}(\mathrm{H})\right)$ is converted the diprotonated complex $\left[\mathrm{Mn}^{\mathrm{III}}(\mathrm{OTf})\left(\mathrm{TBP}{ }_{8} \mathrm{Cz}(\mathrm{H})_{2}\right)\right][\mathrm{OTf}]$, when ${ }^{7} \mathrm{~T}_{1}$ of $\left[\mathrm{Mn}^{\mathrm{III}}(\mathrm{OTf})\left(\mathrm{TBP}_{8} \mathrm{Cz}(\mathrm{H})_{2}\right)\right][\mathrm{OTf}]$ cannot react with $\mathrm{O}_{2}$ to produce the superoxo complex because of the high oxidation potential of $\left[\mathrm{Mn}^{\mathrm{III}}(\mathrm{OTf})\left(\mathrm{TBP}_{8} \mathrm{Cz}(\mathrm{H})_{2}\right)\right][\mathrm{OTf}]$ and thereby the catalytic cycle is stopped. It would be of interest in future efforts to examine other acids in order to elucidate the effect of the $\mathrm{H}^{+}$source and conjugate base on the catalysis.

\section{Supplementary Material}

Refer to Web version on PubMed Central for supplementary material.

\section{Acknowledgments}

This work was supported by Grants-in-Aid (No. 20108010 to S.F. and 23750014 to K.O.), the NSF (CHE0909587, CHE121386 to D.P.G.), the NIH (GM101153 to D.P.G.), and by a Grant-in-Aid (20108010) and an ALCA project (to S.F.) from JST, Japan.

\section{REFERENCES}

1. (a) Ortiz de Montellano, PR., editor. Cytochrome P450: Structure, Mechanism, and Biochemistry. 3rd. New York: Kluwer Academic/Plenum Publishers; 2005. (b) Meunier, B., editor. Metal-Oxo and Metal-Peroxo Species in Catalytic Oxidations. Berlin: Springer-Verlag; 2000. (c) Terner J, Gold A. J. Am. Chem. Soc. 2007; 129:16279-16280.(d) Guengerich FP. Chem. Res. Toxicol. 2001; 14:611650. [PubMed: 11409933] (e) Denisov IG, Makris TM, Sligar SG, Schlichting I. Chem. Rev. 2005; 105:2253-2278. [PubMed: 15941214]

2. (a) Coelho PS, Brustad EM, Kannan A, Arnold FH. Science. 2013; 339:307-310. [PubMed: 23258409] (b) Zhang R, Newcomb M. Acc. Chem. Res. 2008; 41:468-477. [PubMed: 18278877] (c) Meunier B, Visser SP, de Shaik S. Chem. Rev. 2004; 104:3947-3980. [PubMed: 15352783] (d) Franke A, Hessenauer-Ilicheva N, Meyer D, Stochel G, Woggon W-D, van Eldik R. J. Am. Chem. Soc. 2006; 128:13611-13624. [PubMed: 17031976] 
3. (a) Nam W. Acc. Chem. Res. 2007; 40:522-531. [PubMed: 17469792] (b) Czernuszewicz RS, Mody V, Czader A, Gałęzowski M, Gryko DT. J. Am. Chem. Soc. 2009; 131:14214-14215. [PubMed: 19757774] (c) Shaik S, Hirao H, Kumar D. Acc. Chem. Res. 2007; 40:532-542. [PubMed: 17488054] (d) Schmidt A-C, Heinemann FW, Lukens WW Jr, Meyer K. J. Am. Chem. Soc. 2014; 136:11980-11993. [PubMed: 24937106]

4. (a) Collman JP, Slaughter LM, Eberspacher TA, Strassner T, Brauman JI. Inorg. Chem. 2001; 40:6272-6280. [PubMed: 11703130] (b) Crestoni ME, Fornarini S. Inorg. Chem. 2005; 44:53795387. [PubMed: 16022536] (c) Zhou M, Balcells D, Parent AR, Crabtree RH, Eisenstein O. ACS Catal. 2012; 2:208-218.

5. (a) Edwards NY, Eikey RA, Loring MI, Abu-Omar MM. Inorg. Chem. 2005; 44:3700-3708. [PubMed: 15877454] (b) Tahsini L, Bagherzadeh M, Nam W, de Visser SP. Inorg. Chem. 2009; 48:6661-6669. [PubMed: 19469505] (c) Lai S, Lepage CJ, Lee DG. Inorg. Chem. 2002; 41:19541957. [PubMed: 11925193]

6. (a) Ramdhanie B, Telser J, Caneschi A, Zakharov LN, Rheingold AL, Goldberg DP. J. Am. Chem. Soc. 2004; 126:2515-2525. [PubMed: 14982461] (b) Buda BEF, Gribnau MCM, Baerends EJ. J. Am. Chem. Soc. 2004; 126:4355-4365. [PubMed: 15053625] (c) Gupta R, Lacy DC, Bominaar EL, Borovik AS, Hendrich MP. J. Am. Chem. Soc. 2012; 134:9775-9784. [PubMed: 22574962] (d) Yoshizawa K. Acc. Chem. Res. 2006; 39:375-382. [PubMed: 16784215]

7. (a) Kumar D, Hirao H, Shaik S, Kozlowski PM. J. Am. Chem. Soc. 2006; 128:16148-16158. [PubMed: 17165768] (b) Comba P, Maurer M, Vadivelu P. Inorg. Chem. 2009; 48:10389-10396. [PubMed: 19813738] (c) Kumar D, Derat E, Khenkin AM, Neumann R, Shaik S. J. Am. Chem. Soc. 2005; 127:17712-17718. [PubMed: 16351100]

8. (a) Bart SC, Anthon C, Heinemann FW, Bill E, Edelstein NM, Meyer K. J. Am. Chem. Soc. 2008; 130:12536-12546. [PubMed: 18715008] (b) Abbina S, Bian S, Oian C, Du G. ACS Catal. 2013; 3:678-684.(c) Comba P, Maurer M, Vadivelu P. J. Am. Chem. Soc. 2008; 112:13028-13036.(d) Lacy DC, Gupta R, Stone KL, Greaves J, Ziller JW, Hendrich MP, Borovik AS. J. Am. Chem. Soc. 2010; 132:12188-12190. [PubMed: 20704272]

9. (a) Jensen MP, Costas M, Ho RYN, Kaizer J, Payeras AMI, Münck E, Que L Jr, Rohde J-U, Stubna A. J. Am. Chem. Soc. 2005; 127:10512-10525. [PubMed: 16045338] (b) Tooyama Y, Braband H, Spingler B, Abram U, Alberto R. Inorg. Chem. 2008; 47:257-264. [PubMed: 18076160] (c) Fernandes AC, Fernandes JA, Romão CC, Veiros LF, Calhorda MJ. Organometallics. 2010; 29:5517-5525.

10. (a) Slep LD, Mijovilovich A, Meyer-Klaucke W, Weyhermüller T, Bill E, Bothe E, Neese E, Wieghardt K. J. Am. Chem. Soc. 2013; 125:15554-15570. [PubMed: 14664603] (b) Krebs C, Fujimori DC, Walsh CT, Bollinger JM Jr. Acc. Chem. Res. 2007; 40:484-492. [PubMed: 17542550] (c) Martinho M, Banse F, Bartoli J-F, Mattioli TA, Battioni P, Horner O, Bourcier S, Girerd J-J. Inorg. Chem. 2005; 44:9592-9596. [PubMed: 16323949]

11. (a) Gunay A, Theopold KH. Chem. Rev. 2010; 110:1060-1081. [PubMed: 20143877] (b) Yi CS, Zeczycki TN, Guzei IA. Organometallics. 2006; 25:1047-1051. [PubMed: 18726005] (c) Bakac A. J. Am. Chem. Soc. 2000; 122:1092-1097.(d) Czernuszewicz RS, Mody V, Zareba AA, Zaczek MB, Gałęzowski M, Sashuk V, Grela K, Gryko DT. Inorg. Chem. 2007; 46:5616-5624. [PubMed: 17547394]

12. (a) Konar S, Clearfield A. Inorg. Chem. 2008; 47:3489-3491. [PubMed: 18376822] (b) King AE, Nippe M, Atanasov M, Chantarojsiri T, Wray CA, Bill E, Neese F, Long JR, Chang CJ. Inorg. Chem. 2014; 53:11388-11395. [PubMed: 25097094] (c) Vasbinder MJ, Bakac A. Inorg. Chem. 2007; 46:2921-2928. [PubMed: 17290988]

13. (a) Bigi JP, Harman WH, Lassalle-Kaiser B, Robles DM, Stich TA, Yano J, Britt RD, Chang CJ. J. Am. Chem. Soc. 2012; 134:1536-1542. [PubMed: 22214221] (b) Lovell T, Han W-G, Liu T, Noodleman L. J. Am. Chem. Soc. 2002; 124:5890-5894. [PubMed: 12010064] (c) Price JC, Barr EW, Tirupati B, Bollinger JM Jr, Krebs C. Biochemistry. 2003; 42:7497-7508. [PubMed: 12809506] (d) Leeladee P, Jameson GNL, Siegler MA, Kumar D, Visser SP, de Goldberg DP. Inorg. Chem. 2013; 52:4668-4682. [PubMed: 23527920]

14. (a) Liu S, Mase K, Bougher C, Hicks SD, Abu-Omar MM, Fukuzumi S. Inorg. Chem. 2014; 53:7780-7788. [PubMed: 24988040] (b) Zall CM, Clouston LJ, Young VG Jr, Ding K, Kim HJ, Zherebetskyy D, Chen YS, Bill E, Gagliardi L, Lu CC. Inorg. Chem. 2013; 52:9216-9228. 
[PubMed: 23902538] (c) Groysman S, Villagrán D, Nocera DG. Inorg. Chem. 2010; 49:10759_ 10761. [PubMed: 21049961]

15. Prokop KA, Goldberg DP. J. Am. Chem. Soc. 2012; 134:8014-8017. [PubMed: 22533822]

16. Jung J, Ohkubo K, Prokop KA, Neu HM, Goldberg DP, Fukuzumi S. Inorg. Chem. 2013; 52:13594-13604. [PubMed: 24219426]

17. (a) Goldberg DP. Acc. Chem. Res. 2007; 40:626-634. [PubMed: 17580977] (b) Conradie J, Swarts JC, Ghosh A. J. Phys. Chem. B. 2004; 108:452-456.(c) Venkataramanan NS, Premsingh S, Rajagopal S, Pitchumani K. J. Org. Chem. 2003; 68:7460-7470. [PubMed: 12968901] (d) Sugimoto H, Kitayama K, Ashikari K, Matsunami C, Ueda N, Umakoshi K, Hosokoshi Y, Sasaki Y, Itoh S. Inorg. Chem. 2011; 50:9014-9023. [PubMed: 21827180]

18. (a) Meier-Callahan AE, Gray HB, Gross Z. Inorg. Chem. 2000; 39:3605-3607. [PubMed: 11196822] (b) Vanover E, Huang Y, Xu L, Newcomb M, Zhang R. Org. Lett. 2010; 12:2246-2249. [PubMed: 20394434] (c) Chung LW, Lee HG, Lin Z, Wu Y-D. J. Org. Chem. 2006; 71:6000-6009. [PubMed: 16872182] (d) Harischandra DN, Lowery G, Zhang R, Newcomb M. Org. Lett. 2009; 11:2089-2092. [PubMed: 19361171]

19. (a) McGown AJ, Kerber WD, Fujii H, Goldberg DP. J. Am. Chem. Soc. 2009; 131:8040-8048. [PubMed: 19462977] (b) Kang M-J, Song WJ, Han A-R, Choi YS, Jang HG, Nam W. J. Org. Chem. 2007; 72:6301-6304. [PubMed: 17622172] (c) Nam W, Lee Y-M, Fukuzumi S. Acc. Chem. Res. 2014; 47:1146-1154. [PubMed: 24524675]

20. (a) Mitić N, Clay MD, Saleh L, Bollinger JM Jr, Solomon EI. J. Am. Chem. Soc. 2007; 129:90499065. [PubMed: 17602477] (b) Chen H, Lai W, Shaik S. J. Phys. Chem. Lett. 2010; 1:1533-1540. (c) Chiavarino B, Cipollini R, Crestoni ME, Fornarini S, Lanucara S, Lapi A. J. Am. Chem. Soc. 2008; 130:3208-3217. [PubMed: 18278912]

21. (a) Pan Z, Newcomb M. Inorg. Chem. 2007; 46:6767-6774. [PubMed: 17630728] (b) Chung LW, Li X, Hirao H, Morokuma K. J. Am. Chem. Soc. 2011; 133:20076-20079. [PubMed: 22047171] (c) Pan Z, Wang Q, Sheng X, Horner JH, Newcomb M. J. Am. Chem. Soc. 2009; 131:2621-2628. [PubMed: 19193008]

22. (a) Pestovsky O, Bakac O. J. Am. Chem. Soc. 2003; 125:14714-14715. [PubMed: 14640640] (b) Betley TA, Wu Q, Voorhis TV, Nocera DG. Inorg. Chem. 2008; 47:1849-1861. [PubMed: 18330975]

23. (a) Taguchi T, Gupta R, Lassalle-Kaiser B, Boyce DW, Yachandra VK, Tolman WB, Yano J, Hendrich MP, Borovik AS. J. Am. Chem. Soc. 2012; 134:1996-1999. [PubMed: 22233169] (b) Harischandra DN, Zhang R, Newcomb M. J. Am. Chem. Soc. 2005; 127:13776-13777. [PubMed: 16201783]

24. (a) McEvoy JP, Brudvig GW. Chem. Rev. 2006; 106:4455-4483. [PubMed: 17091926] (b) Umena Y, Kawakami K, Shen J-R, Kamiya N. Nature. 2011; 473:55-60. [PubMed: 21499260] (c) Vaddypally S, Kondaveeti SK, Zdilla MJ. Inorg. Chem. 2012; 51:3950-3952. [PubMed: 22439626] (d) Suga M, Akita F, Hirata K, Ueno G, Murakami H, Nakajima Y, Shimizu T, Yamashita K, Yamamoto M, Ago H, Shen J-R. Nature. 2015; 517:99. [PubMed: 25470056]

25. (a) Lansky DE, Goldberg DP. Inorg. Chem. 2006; 45:5119-5125. [PubMed: 16780334] (b) Cho K, Leeladee P, McGown AJ, DeBeer S, Goldberg DP. J. Am. Chem. Soc. 2012; 134:7392-7399. [PubMed: 22489757] (c) Prokop KA, Neu HM, Visser SP, de Goldberg DP. J. Am. Chem. Soc. 2011; 133:15874-15877. [PubMed: 21888343] (d) Leeladee P, Goldberg DP. Inorg. Chem. 2010; 49:3083-3085. [PubMed: 20201529]

26. (a) Zhang R, Newcomb M. J. Am. Chem. Soc. 2003; 125:12418-12419. [PubMed: 14531679] (b) Kumar A, Goldberg I, Botoshansky M, Buchman Y, Gross Z. J. Am. Chem. Soc. 2010; 132:15233-15245. [PubMed: 20932015] (c) Parsell TH, Behan RK, Green MT, Hendrich MP, Borovik AS. J. Am. Chem. Soc. 2006; 128:8728-8729. [PubMed: 16819856]

27. (a) Shirin Z, Hammes BS, Young VG Jr, Borovik AS. J. Am. Chem. Soc. 2000; 122:1836-1837.(b) Zdilla MJ, Abu-Omar MM. J. Am. Chem. Soc. 2006; 128:16971-16979. [PubMed: 17177448]

28. (a) Fukuzumi S, Fujioka N, Kotani H, Ohkubo K, Lee Y-M, Nam W. J. Am. Chem. Soc. 2009; 131:17127-17134. [PubMed: 19888722] (b) Lee JY, Lee Y-M, Kotani H, Nam W, Fukuzumi S. Chem. Commun. 2009:704-706.(c) Prokop KA, Visser SP, de Goldberg DP. Angew. Chem. 2010; 2010; 122:5217-5221.Angew. Chem. Int. Ed. 2010; 49:5091-5095.(d) Fukuzumi S, Kotani H, Prokop KA, Goldberg DP. J. Am. Chem. Soc. 2011; 133:1859-1869. [PubMed: 21218824] 
29. (a) Yin G. Acc. Chem. Res. 2013; 46:483-492. [PubMed: 23194251] (b) Zhang R, Horner JH, Newcomb M. J. Am. Chem. Soc. 2005; 127:6573-6582. [PubMed: 15869278] (c) Angelis FD, Jin N, Car R, Groves JT. Inorg. Chem. 2006; 45:4268-4276. [PubMed: 16676990] (d) Arunkumar C, Lee Y-M, Lee JY, Fukuzumi S, Nam W. Chem.-Eur. J. 2009; 15:11482-11489. [PubMed: 19810056]

30. (a) Mukhopadhyay S, Gandhi BA, Kirk ML, Armstrong WH. Inorg. Chem. 2003; 42:8171-8180. [PubMed: 14658867] (b) Kurahashi T, Kikuchi A, Shiro Y, Hada M, Fujii H. Inorg. Chem. 2010; 49:6664-6672. [PubMed: 20553024] (c) Pecoraro VL, Hsieh W-Y. Inorg. Chem. 2008; 47:17651778. [PubMed: 18330968]

31. (a) Lansky DE, Kosack JR, Sarjeant AAN, Goldberg DP. Inorg. Chem. 2006; 45:8477-8479. [PubMed: 17029354] (b) Wang SH, Mandimutsira BS, Todd R, Ramdhanie B, Fox JP, Goldberg DP. J. Am. Chem. Soc. 2004; 126:18-19. [PubMed: 14709038] (c) Lewis RA, Wu G, Hayton TW. Inorg. Chem. 2011; 50:4660-4668. [PubMed: 21486021]

32. (a) Shen D, Miao C, Wang S, Xia C, Sun W. Org. Lett. 2014; 16:1108-1111. [PubMed: 24499500] (b) Gómez-Hortigüela L, Corà F, Catlow CRA. ACS Catal. 2011; 1:18-28.(c) Krewald V, Neese F, Pantazis DA. J. Am. Chem. Soc. 2013; 135:5726-5739. [PubMed: 23527603]

33. Jung J, Ohkubo K, Goldberg DP, Fukuzumi S. J. Phys. Chem. A. 2014; 118:6223-6229. [PubMed: 25079061]

34. (a) Morimoto Y, Kotani H, Park J, Lee Y, Nam W, Fukuzumi S. J. Am. Chem. Soc. 2011; 133:403405. [PubMed: 21158434] (b) Fukuzumi S, Morimoto Y, Kotani H, Naumov P, Lee Y, Nam W. Nat. Chem. 2010; 2:756-759. [PubMed: 20729896] (c) Fukuzumi S, Ohkubo K, Morimoto Y. Phys. Chem. Chem. Phys. 2012; 14:8472-8484. [PubMed: 22596095] (d) Fukuzumi S, Ohkubo K. Coord. Chem. Rev. 2010; 254:372-385.

35. (a) Chen J, Lee Y, Davis KM, Wu X, Seo MS, Cho K, Yoon H, Park YJ, Fukuzumi S, Pushkar YN, Nam W. J. Am. Chem. Soc. 2013; 135:6388-6391. [PubMed: 23324100] (b) Yoon H, Lee Y-M, Wu X, Cho K-B, Sarangi R, Nam W, Fukuzumi S. J. Am. Chem. Soc. 2013; 135:9186-9194. [PubMed: 23742163] (c) Li F, Heuvelen KM, van Meier KK, Münck E, Que L Jr. J. Am. Chem. Soc. 2013; 135:10198-10201. [PubMed: 23802702]

36. Park YJ, Ziller JW, Borovik AS. J. Am. Chem. Soc. 2011; 133:9258-9261. [PubMed: 21595481]

37. (a) Park YJ, Cook SA, Sickerman NS, Sano Y, Ziller JW, Borovik AS. Chem. Sci. 2013; 4:717726. [PubMed: 24058726] (b) Lee YM, Bang S, Kim YM, Cho J, Hong S, Nomura T, Ogura T, Troeppner O, Ivanovic- Burmazovic I, Sarangi R, Fukuzumi S, Nam W. Chem. Sci. 2013; 4:39173923. [PubMed: 25426288] (c) Yin G, Danby AM, Kitko D, Carter JD, Scheper WM, Busch DH. J. Am. Chem. Soc. 2008; 130:16245-16253. [PubMed: 18998682]

38. (a) Park J, Morimoto Y, Lee Y-M, Nam W, Fukuzumi S. Inorg. Chem. 2014; 53:3618-3628. [PubMed: 24605985] (c) Park J, Lee Y-M, Nam W, Fukuzumi S. J. Am. Chem. Soc. 2013; 135:5052-5061. [PubMed: 23528016]

39. (a) Du H, Lo P, Hu Z, Liang H, Lau K, Wang YN, Lam WWY, Lau TC. Chem. Commun. 2011; 47:7143-7145.(b) Yiu S-M, Man W-L, Lau T-C. J. Am. Chem. Soc. 2008; 130:10821-10827. [PubMed: 18642814] (c) Lam WWY, Yiu S-M, Lee JMN, Yau SKY, Kwong H-K, Lau T-C, Liu D, Lin Z. J. Am. Chem. Soc. 2006; 128:2851-2858. [PubMed: 16506763] (d) Yiu S-M, Wu Z-B, Mak C-K, Lau T-C. J. Am. Chem. Soc. 2004; 126:14921-14929. [PubMed: 15535719]

40. (a) Herbert DE, Lionetti D, Rittle J, Agapie T. J. Am. Chem. Soc. 2013; 135:19075-19078. [PubMed: 24304416] (b) Smeltz JL, Lilly CP, Boyle PD, Ison EA. J. Am. Chem. Soc. 2013; 135:9433-9441. [PubMed: 23725588] (c) Asao N, Sato K. Org. Lett. 2006; 8:5361-5363. [PubMed: 17078718]

41. (a) Tsui EY, Tran R, Yano J, Agapie T. Nat. Chem. 2013; 5:293-299. [PubMed: 23511417] (b) Das D, Lee Y-M, Ohkubo K, Nam W, Karlin K, D; Fukuzumi S. J. Am. Chem. Soc. 2013; 135:40184026. [PubMed: 23442145] (c) Das D, Lee Y-M, Ohkubo K, Nam W, Karlin KD, Fukuzumi S. J. Am. Chem. Soc. 2013; 135:2825-2834. [PubMed: 23394287]

42. (a) Leeladee P, Baglia RA, Prokop KA, Latifi R, de Visser SP, Goldberg DP. J. Am. Chem. Soc. 2012; 134:10397-10400. [PubMed: 22667991] (b) Baglia RA, Dürr M, Ivanovic-Burmazovic I, Goldberg DP. Inorg. Chem. 2014; 53:5893-5895. [PubMed: 24873989] (c) Zaragoza JPT, Baglia RA, Siegler MA, Goldberg DP. J. Am. Chem. Soc. 2015; 137:6531-6540. [PubMed: 25964988] 
43. Neu HM, Jung J, Baglia RA, Siegler MA, Ohkubo K, Fukuzumi S, Goldberg DP. J. Am. Chem. Soc. 2015; 137:4614-4617. [PubMed: 25839905]

44. (a) Rauchfuss TB. Acc. Chem. Res. 2015; 48:2107-2116. [PubMed: 26079848] (b) Fukuzumi S, Tahsini L, Lee Y-M, Ohkubo K, Nam W. J. Am. Chem. Soc. 2012; 134:7025-7035. [PubMed: 22462521] (c) Svetlanova-Larsen A, Zoch CR, Hubbard JL. Organometallics. 1996; 15:30763087.

45. (a) Labios LA, Heiden ZM, Mock MT. Inorg. Chem. 2015; 54:4409-4422. [PubMed: 25871448]

(b) Yue NLS, Jennings MC, Puddephatt RJ. Inorg. Chem. 2005; 44:1125-1131. [PubMed: 15859294] (c) del Río I, Gossage RA, Hannu MS, Lutz M, Spek AL, van Koten G. Organometallics. 1999; 18:1097-1105.

46. (a) Lansky DE, Mandimutsira B, Ramdhanie B, Clausen M, Penner-Hahn J, Zvyagin SA, Telser J, Krzystek J, Zhan R, Ou Z, Kadish KM, Zakharov L, Rheingold AL, Goldberg DP. Inorg. Chem. 2005; 44:4485-4498. [PubMed: 15962955] (b) Ramdhanie B, Stern CL, Goldberg DP. J. Am. Chem. Soc. 2001; 123:9447-9448. [PubMed: 11562230] (c) Mandimutsira BS, Ramdhanie B, Todd RC, Wang HL, Zareba AA, Czernuszewicz RS, Goldberg DP. J. Am. Chem. Soc. 2002; 124:15170-15171. [PubMed: 12487581]

47. Armarego, WLF.; Perrin, DD., editors. Purification of Laboratory Chemicals. Oxford: Pergamon Press; 1997.

48. (a) Sheldrick GM. Acta Crystallogr. C. 2008; A64:112-122.(b) Sheldrick GM. Acta Crystallogr. C. 2015; 71:3-8.

49. Spek AL. J. Appl. Cryst. 2003; 36:7-13.

50. Hatchard CG, Parker CA. Proc. R. Soc. London, Ser. A. 1956; 235:518-536.

51. (a) Neu HM, Quesne MG, Yang T, Prokop-Prigge KA, Lancaster KM, Donohoe J, DeBeer S, de Visser SP, Goldberg DP. Chem.-Eur. J. 2014; 20:14584-14588. [PubMed: 25256417] (b) Neu HM, Yang T, Baglia RA, Yosca TH, Green MT, Quesne MG, de Visser SP, Goldberg DP. J. Am. Chem. Soc. 2014; 136:13845-13852. [PubMed: 25238495]

52. Punniyamurthy T, Velusamy S, Iqbal J. Chem. Rev. 2005; 105:2329-2363. [PubMed: 15941216]

53. Pistorio BJ, Chang CJ, Nocera DG. J. Am. Chem. Soc. 2002; 124:7884-7885. [PubMed: 12095316]

54. Zhou X-T, Ji H-B. Catal. Commun. 2014; 53:29-32.

55. Kim Y, Choi JR, Yoon M. J. Phys. Chem. B. 2001; 105:8513-8518.

56. (a) Humphrey JL, Kuciauskas D. J. Am. Chem. Soc. 2006; 128:3902-3903. [PubMed: 16551085] (b) Spänig F, Ruppert M, Dannhäuser J, Hirsch A, Guldi DM. J. Am. Chem. Soc. 2009; 131:93789388. [PubMed: 19566102] (c) Gonçalves PJ, De Boni L, Borissevitch IE, Zílio SC. J. Phys. Chem. A. 2008; 112:6522-6526. [PubMed: 18588273] (d) Krokos E, Spänig F, Ruppert M, Hirsch A, Guldi DM. Chem.-Eur. J. 2012; 18:1328-1341. [PubMed: 22213484]

57. (a) Cho J, Sarangi R, Nam W. Acc. Chem. Res. 2012; 45:1321-1330. [PubMed: 22612523] (b) Peterson RL, Himes RA, Kotani H, Suenobu T, Tian L, Siegler MA, Solomon EI, Fukuzumi S, Karlin KD. J. Am. Chem. Soc. 2011; 133:1702-1705. [PubMed: 21265534] (c) Cho J, Woo J, Nam W. J. Am. Chem. Soc. 2010; 132:5958-5959. [PubMed: 20392047] (d) Nemes A, Bakac A. Inorg. Chem. 2001; 40:746-749. [PubMed: 11225118]

58. (a) Clennan EL, Greer AJ. Org. Chem. 1996; 61:4793-4797.(b) Bonesi SM, Albini AJ. Org. Chem. 2000; 65:4532-4536.(c) Baciocchi E, Chiappe C, Fasciani C, Lanzalunga O, Lapi A. Org. Lett. 2010; 12:5116-5119. [PubMed: 21028790] 
(a)

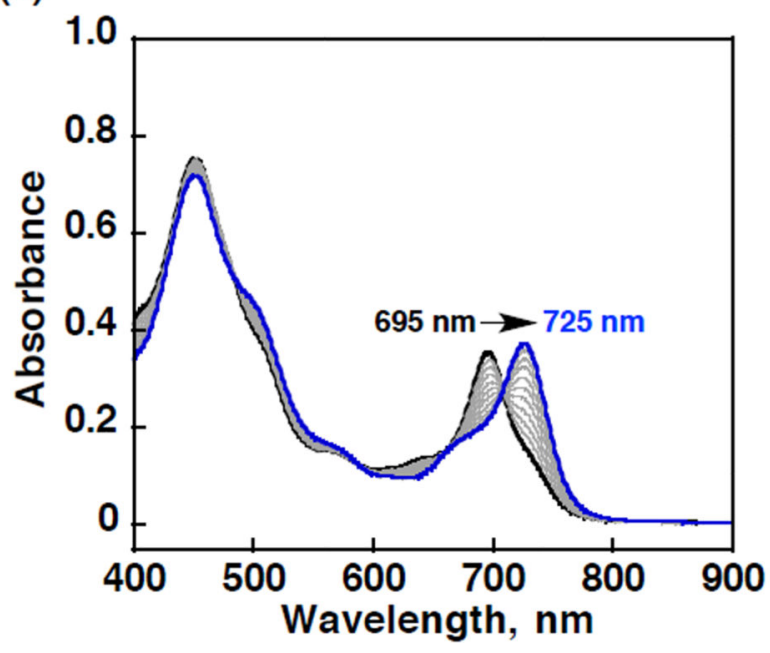

(b)

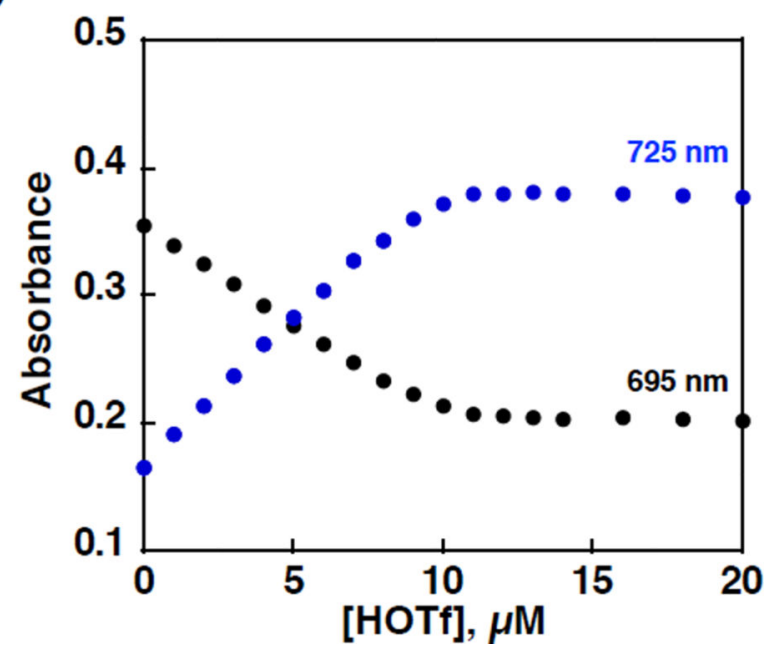

Figure 1.

(a) UV-vis spectral changes and (b) plot for determination of the binding constant of the conversion from $\mathrm{Mn}^{\mathrm{III}}\left(\mathrm{TBP}_{8} \mathrm{Cz}\right)$ (black line, $\left.1.0 \times 10^{-5} \mathrm{M}\right)$ to $\mathrm{Mn}^{\mathrm{III}}(\mathrm{OTf})\left(\mathrm{TBP}_{8} \mathrm{Cz}(\mathrm{H})\right)$ (blue line) by spectroscopic titration of HOTf $\left(0-2.0 \times 10^{-5} \mathrm{M}\right)$ monitored at $695 \mathrm{~nm}$ $\left(\mathrm{Mn}^{\mathrm{III}}\left(\mathrm{TBP}_{8} \mathrm{Cz}\right)\right.$, black dots $)$ and $725 \mathrm{~nm}\left(\mathrm{Mn}^{\mathrm{III}}(\mathrm{OTf})\left(\mathrm{TBP}_{8} \mathrm{Cz}(\mathrm{H})\right)\right.$, blue dots $)$ in a $\mathrm{PhCN}$ solution at room temperature. 
(a)

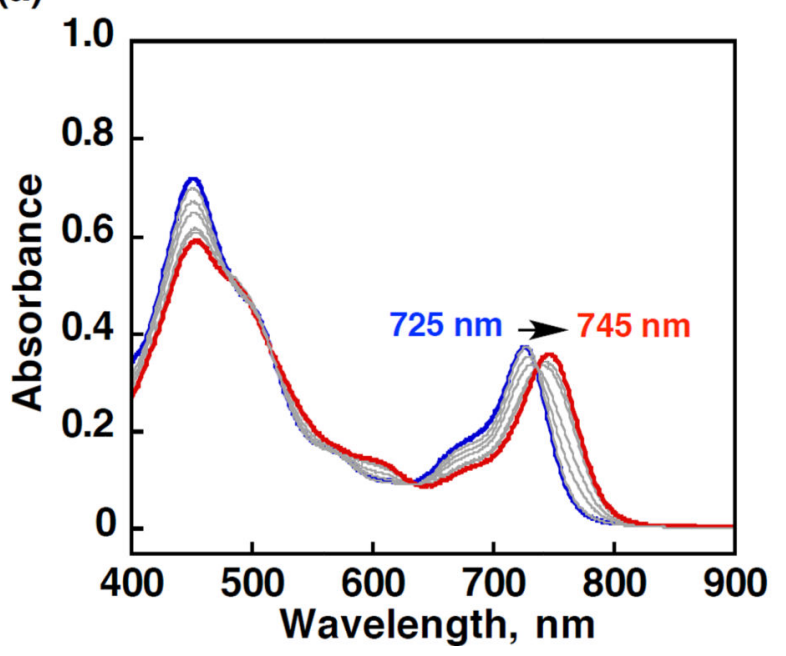

(b)

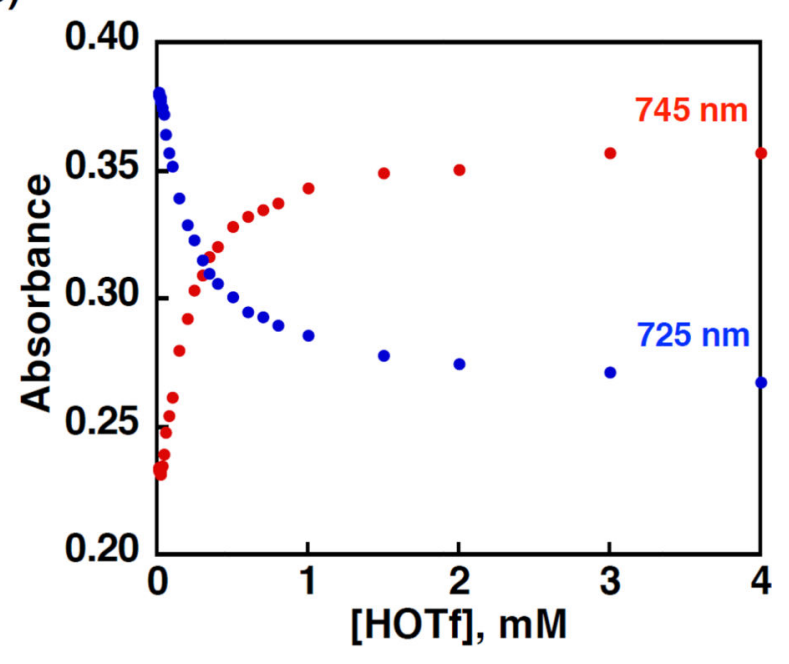

Figure 2.

(a) UV-vis spectral changes and (b) plot for determination of the binding constant of the conversion from $\mathrm{Mn}^{\mathrm{III}}(\mathrm{OTf})\left(\mathrm{TBP}_{8} \mathrm{Cz}(\mathrm{H})\right)$ (blue line, $\left.1.0 \times 10^{-5} \mathrm{M}\right)$ to $\left[\mathrm{Mn}^{\mathrm{III}}(\mathrm{OTf})\left(\mathrm{TBP}_{8^{-}}\right.\right.$ $\left.\left.\mathrm{Cz}(\mathrm{H})_{2}\right)\right][\mathrm{OTf}]$ (red line) by spectroscopic titration of $\operatorname{HOTf}\left(1.0 \times 10^{-5}-1.0 \times 10^{-2} \mathrm{M}\right)$ monitored at $725 \mathrm{~nm}\left(\mathrm{Mn}^{\mathrm{III}}(\mathrm{OTf})\left(\mathrm{TBP}_{8} \mathrm{Cz}(\mathrm{H})\right)\right.$, blue dots $)$ and $745 \mathrm{~nm}\left(\left[\mathrm{Mn}^{\mathrm{III}}(\mathrm{OTf})\right.\right.$ $\left.\left(\mathrm{TBP}_{8} \mathrm{Cz}-(\mathrm{H})_{2}\right)\right][\mathrm{OTf}]$, red dots) in a $\mathrm{PhCN}$ solution at room temperature. 
(a)
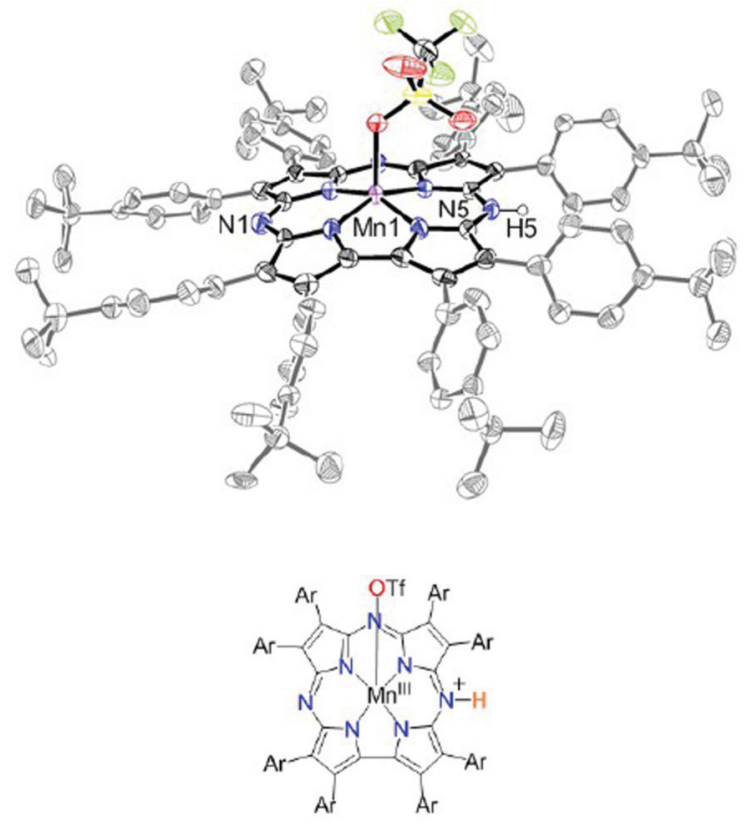

(b)
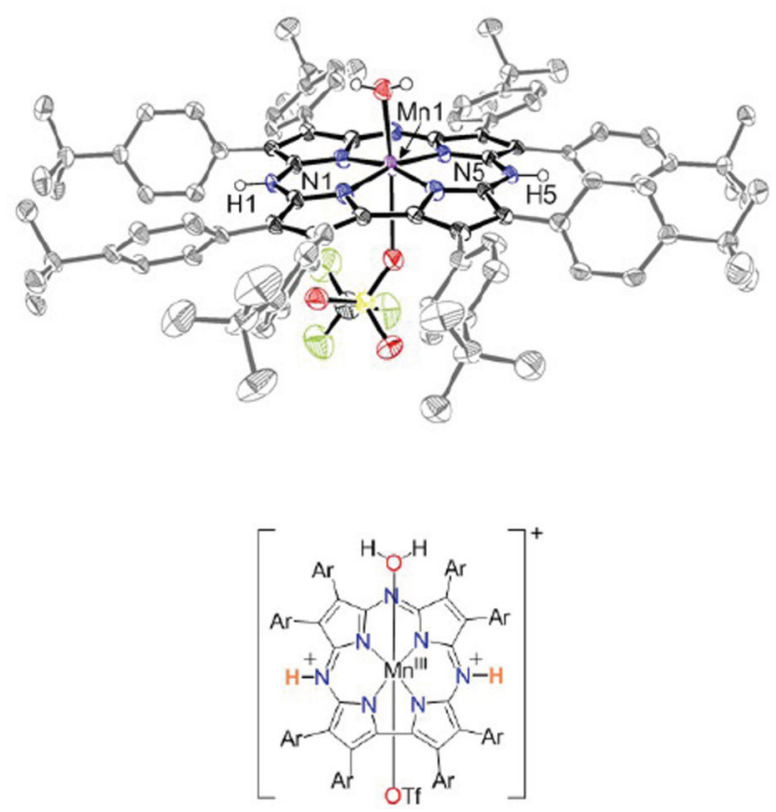

Figure 3.

Displacement ellipsoid plots (50\% probability level) and chemical structures for (a) $\left[\mathrm{Mn}^{\mathrm{III}}(\mathrm{OTf})\left(\mathrm{TBP}_{8} \mathrm{Cz}(\mathrm{H})\right)\right]$ and $(\mathrm{b})\left[\mathrm{Mn}^{\mathrm{III}}(\mathrm{OTf})\left(\mathrm{H}_{2} \mathrm{O}\right)\left(\mathrm{TBP}_{8} \mathrm{Cz}(\mathrm{H})_{2}\right)\right][\mathrm{OTf}]$ at $110(2) \mathrm{K}$. 
(a)

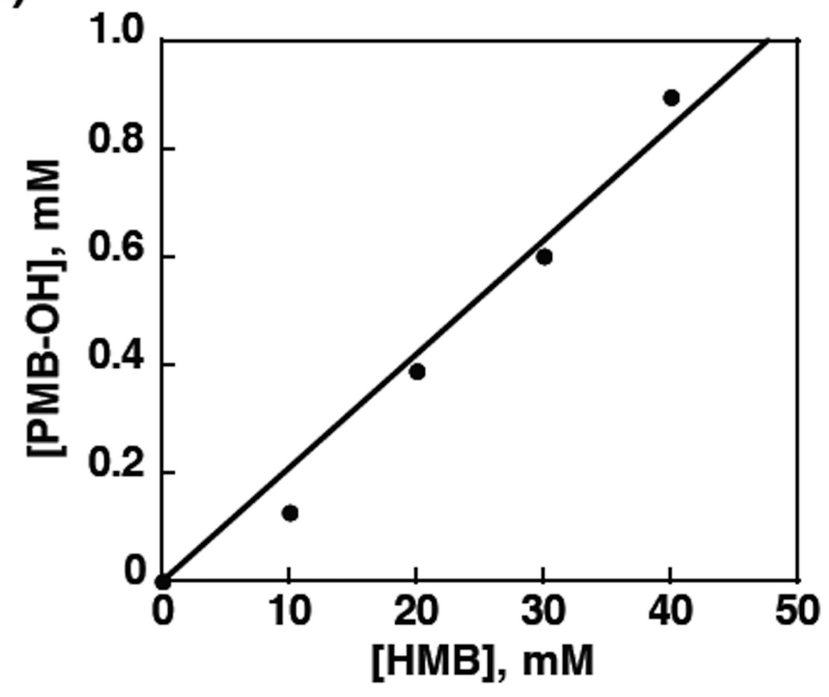

(b)

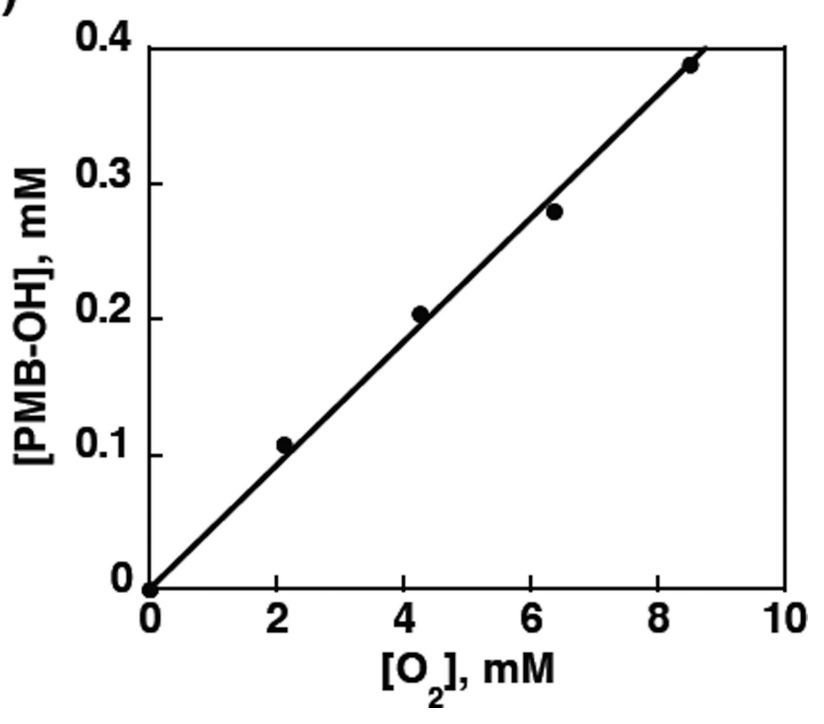

Figure 4.

(a) Plots of the amount of produced pentamethylbenzyl alcohol for photocatalytic oxygenation of $\mathrm{HMB}\left(0-4.0 \times 10^{-2} \mathrm{M}\right)$ by $\mathrm{Mn}^{\mathrm{III}}\left(\mathrm{TBP}_{8} \mathrm{Cz}\right)\left(1.0 \times 10^{-5} \mathrm{M}\right)$ in the presence of $\operatorname{HOTf}\left(4.0 \times 10^{-5} \mathrm{M}\right)$ in an 02 -saturated PhCN solution and (b) Plots of the amount of produced pentamethylbenzyl alcohol for photocatalytic oxygenation of HMB $\left(2.0 \times 10^{-2} \mathrm{M}\right)$ by $\mathrm{Mn}^{\mathrm{III}}\left(\mathrm{TBP}_{8} \mathrm{Cz}\right)\left(1.0 \times 10^{-5} \mathrm{M}\right)$ in the presence of $\mathrm{HOTf}\left(4.0 \times 10^{-5} \mathrm{M}\right)$ in a $\mathrm{PhCN}$ solution vs the oxygen concentration $\left(0-8.5 \times 10^{-3} \mathrm{M}\right)$ under photoirradiation (white light) for $1 \mathrm{~h}$ at room temperature. 


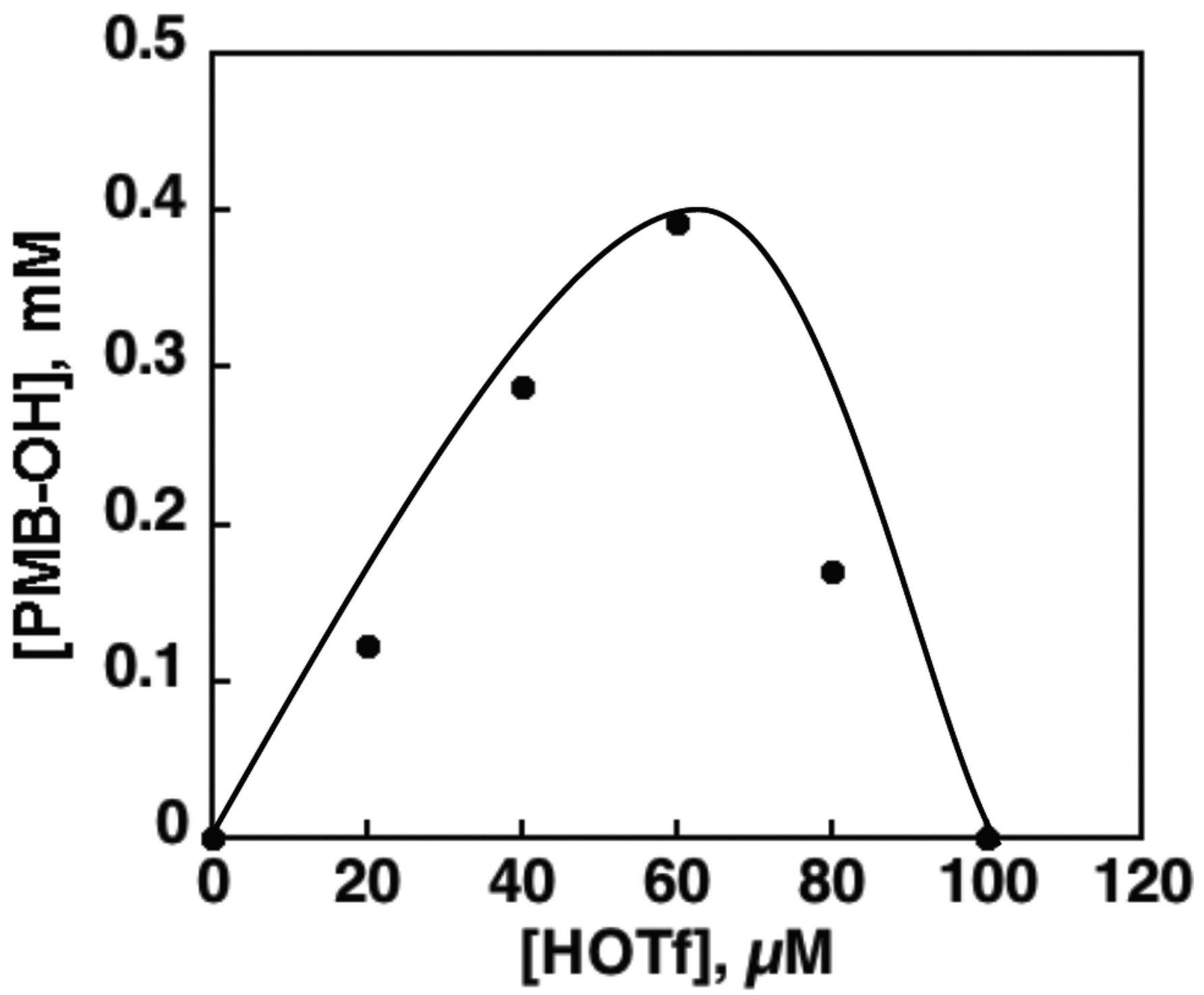

Figure 5.

Plots of the amount of produced pentamethylbenzyl alcohol for photocatalytic oxygenation of $\mathrm{HMB}\left(2.0 \times 10^{-2} \mathrm{M}\right)$ by $\mathrm{Mn}^{\mathrm{III}}\left(\mathrm{TBP}_{8} \mathrm{Cz}\right)\left(1.0 \times 10^{-5} \mathrm{M}\right)$ in the presence of HOTf $(0-1.0$ $\times 10^{-4} \mathrm{M}$ ) under photoirradiation (white light) for $30 \mathrm{~min}$ in an $\mathrm{O}_{2}$-saturated $\mathrm{PhCN}$ solution at room temperature. 


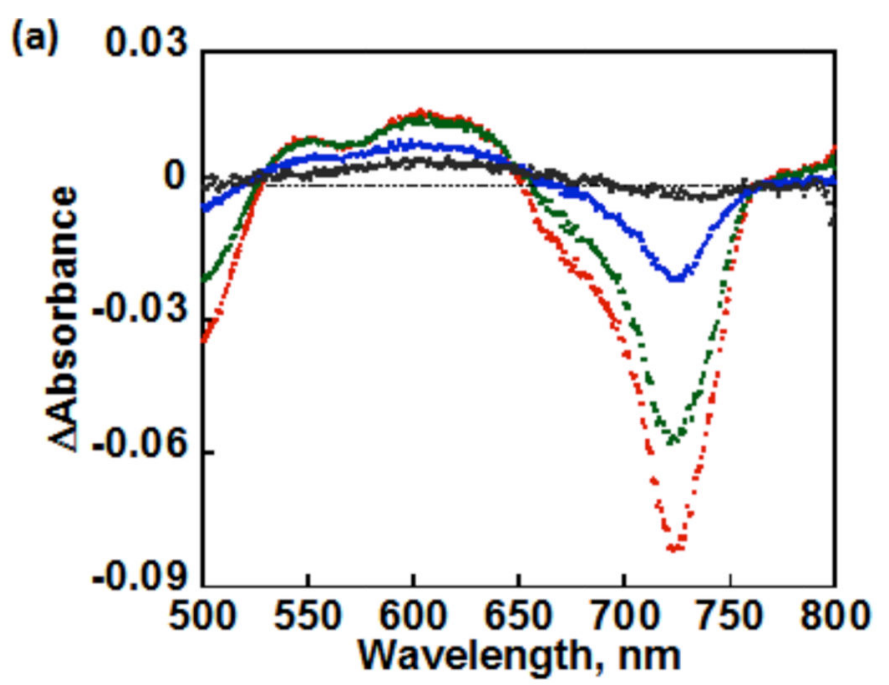

(b)

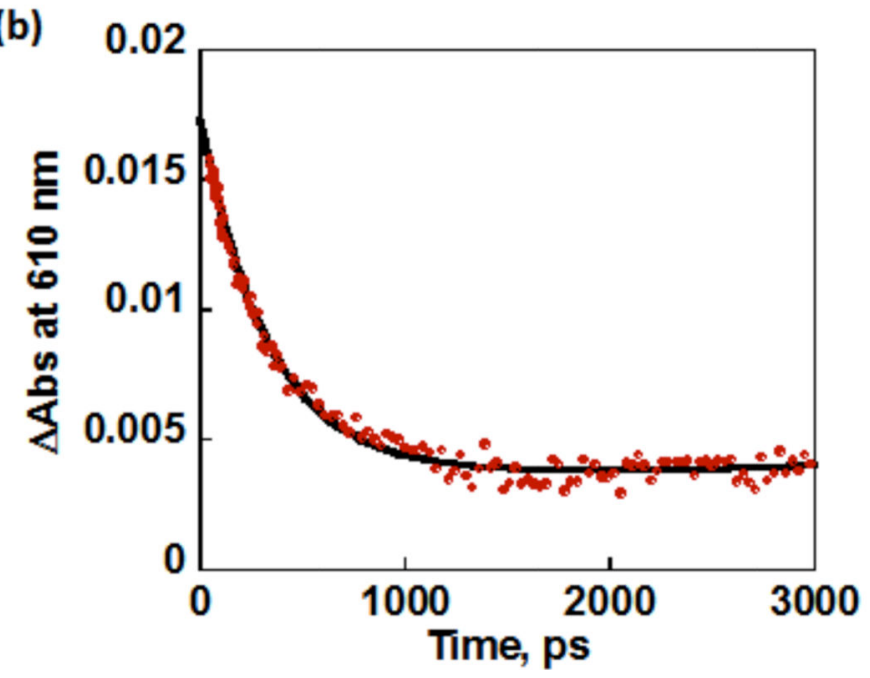

(c)

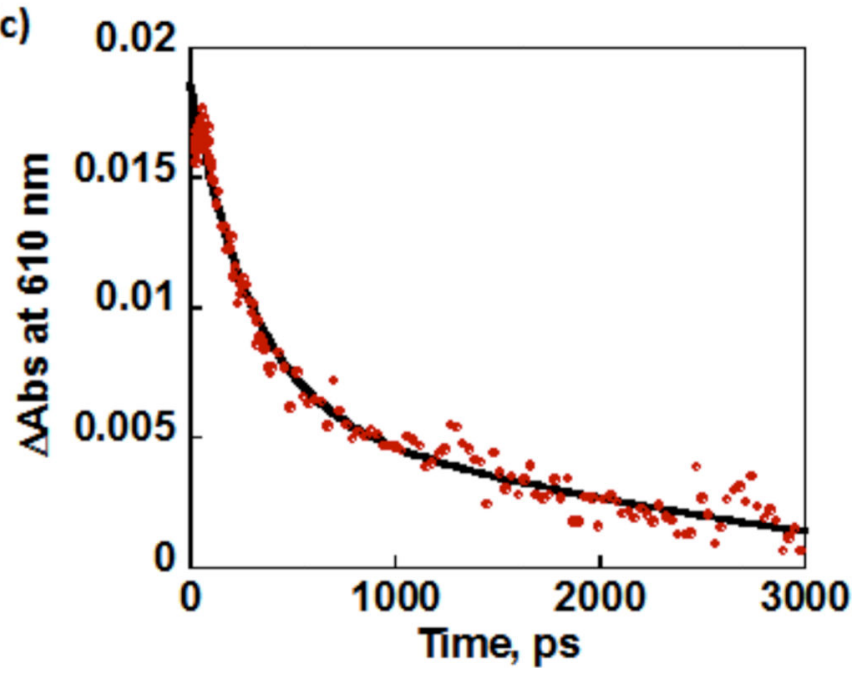

Figure 6.

(a) Transient absorbance spectral changes (red after 10 ps, green 100 ps, blue 500 ps, and black $3000 \mathrm{ps}$ ) after photoexcitation of $\mathrm{Mn}^{\mathrm{III}}(\mathrm{OTf})\left(\mathrm{TBP}_{8} \mathrm{Cz}(\mathrm{H})\right)$ in $\mathrm{PhCN}$. Time profile of the generation and decay of $\left\{\mathrm{Mn}^{\mathrm{III}}(\mathrm{OTf})\left(\mathrm{TBP}_{8} \mathrm{Cz}(\mathrm{H})\right)\right\}^{*}$ at $\lambda=610 \mathrm{~nm}$ under (b) $\mathrm{N}_{2}$ and (c) $\mathrm{O}_{2}$. The black lines are exponential fitting given in eqs 1 and 2 . 


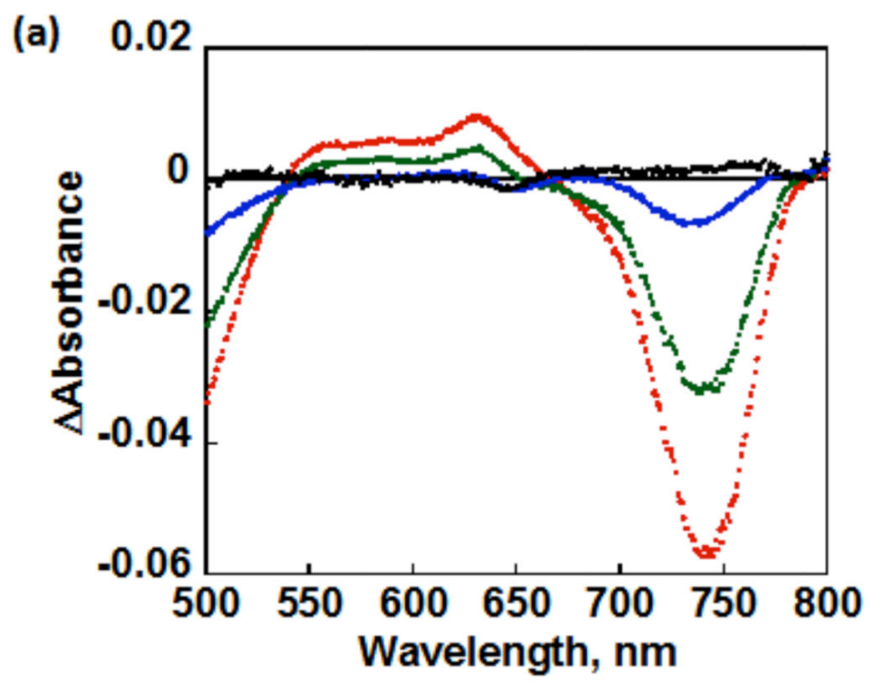

(b)

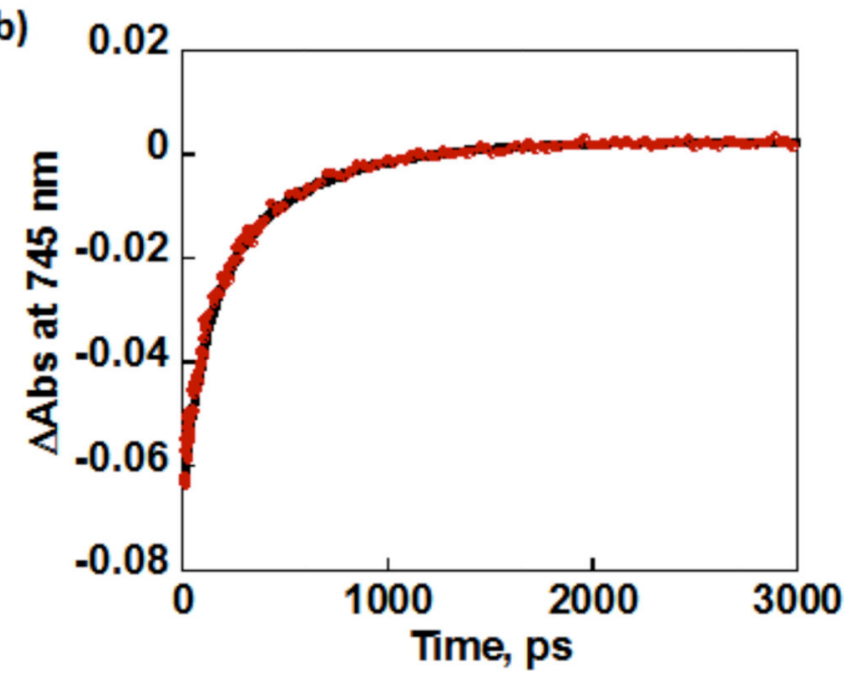

(c)

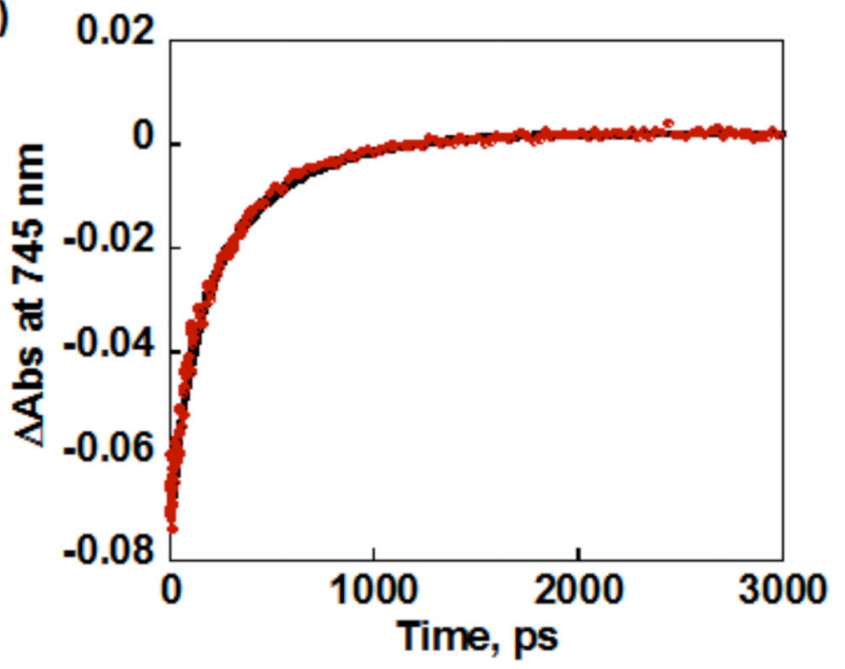

Figure 7.

(a) Transient absorbance spectral changes (red after $10 \mathrm{ps}$, green $100 \mathrm{ps}$, blue $500 \mathrm{ps}$, and black $3000 \mathrm{ps}$ ) after photoexcitation of $\left[\mathrm{Mn}^{\mathrm{III}}(\mathrm{OTf})\left(\mathrm{H}_{2} \mathrm{O}\right)\left(\mathrm{TBP}_{8} \mathrm{Cz}(\mathrm{H})_{2}\right)\right][\mathrm{OTf}]$ in $\mathrm{PhCN}$. Time profile of the generation and decay of $\left\{\left[\mathrm{Mn}^{\mathrm{III}}(\mathrm{OTf})\left(\mathrm{H}_{2} \mathrm{O}\right)\left(\mathrm{TBP}_{8} \mathrm{Cz}(\mathrm{H})_{2}\right)\right][\mathrm{OTf}]\right\}^{*}$ at $\lambda$ $=745 \mathrm{~nm}$ under (b) $\mathrm{N}_{2}$ and (c) $\mathrm{O}_{2}$. The black lines are exponential fitting given in eqs 1 and 2. 
(a)
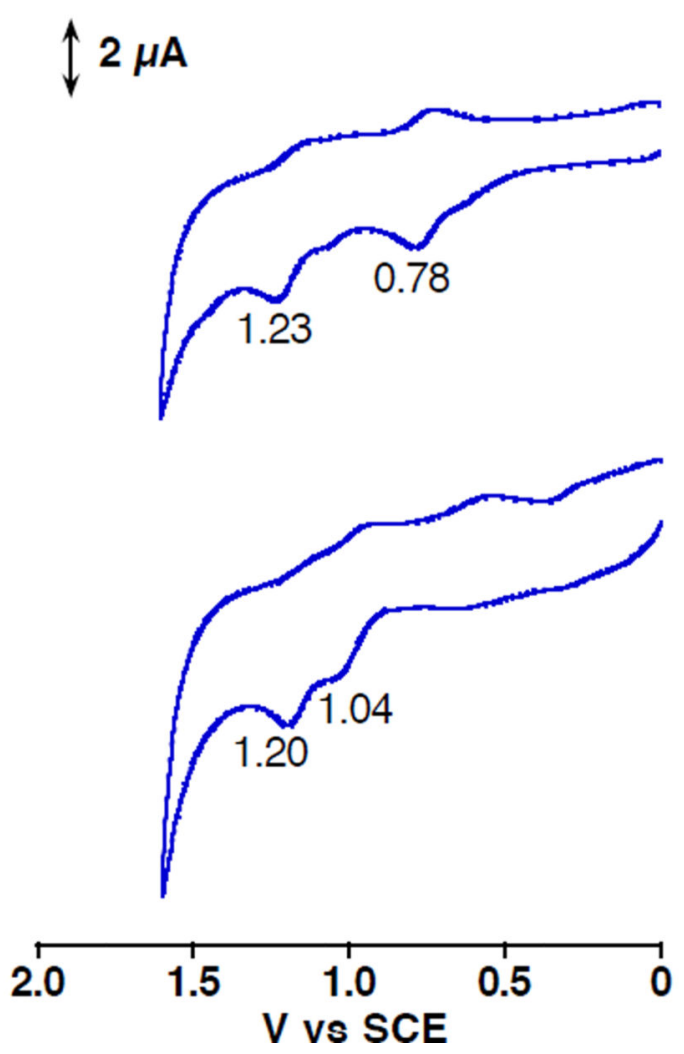

(b)

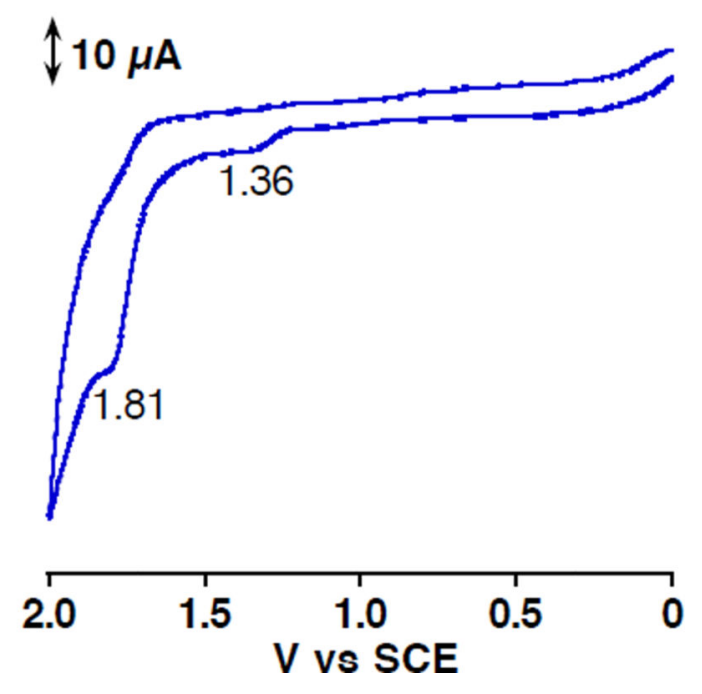

Figure 8.

Cyclic voltammograms of (a) $\mathrm{Mn}^{\mathrm{III}}\left(\mathrm{TBP}_{8} \mathrm{Cz}\right.$ ) (upper, $1.0 \times 10^{-3} \mathrm{M}$ ) in the absence of HOTf and in the presence of HOTf (below, $\left.1.0 \times 10^{-3} \mathrm{M}\right)$, and (b) $\mathrm{Mn}^{\mathrm{III}}\left(\mathrm{TBP}_{8} \mathrm{Cz}\right)\left(1.0 \times 10^{-3} \mathrm{M}\right)$ in the presence of HOTf $(0.1 \mathrm{M})$ in PhCN containing 0.1 M TBAP. Scan rate $=0.10 \mathrm{~V} \mathrm{~s}^{-1}$. 
(a)

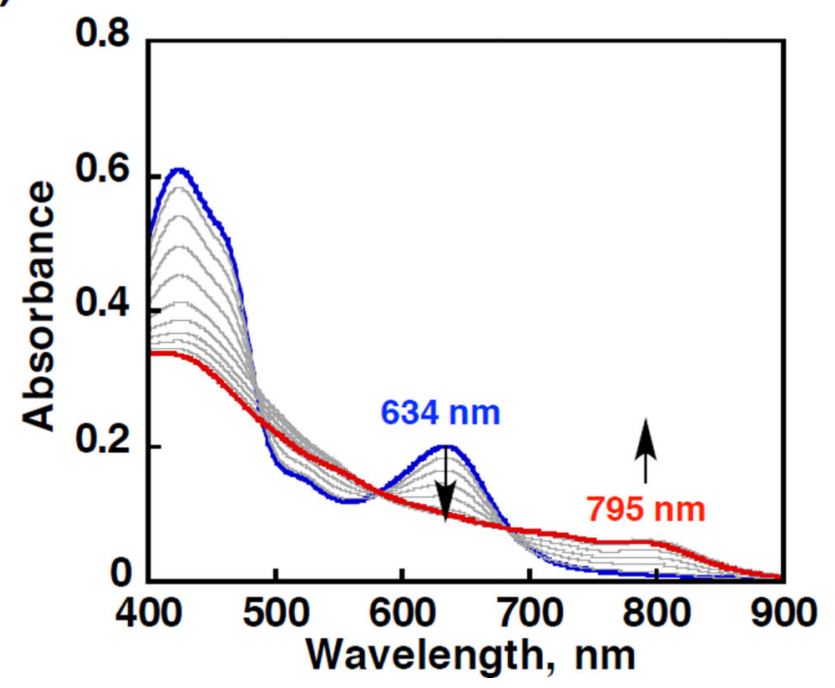

(b)

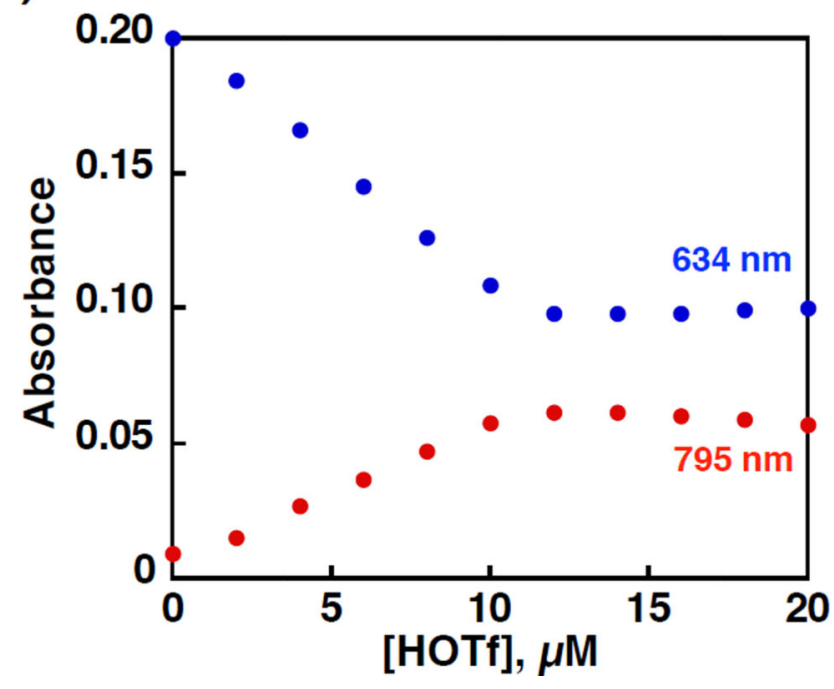

Figure 9.

(a) UV-vis spectral changes and (b) plot for the conversion of $\mathrm{Mn}^{\mathrm{V}}(\mathrm{O})\left(\mathrm{TBP}_{8} \mathrm{Cz}\right.$ ) (blue line, $\left.1.0 \times 10^{-5} \mathrm{M}\right)$ to $\mathrm{Mn}^{\mathrm{IV}}(\mathrm{OH})(\mathrm{OTf})\left(\mathrm{TBP}_{8} \mathrm{Cz}^{\cdot+}\right)$ (red line) by spectroscopic titration of HOTf $\left(0-2.0 \times 10^{-5} \mathrm{M}\right)$ monitored at $634 \mathrm{~nm}\left(\mathrm{Mn}^{\mathrm{V}}(\mathrm{O})\left(\mathrm{TBP}_{8} \mathrm{Cz}\right)\right.$, blue dots $)$ and $795 \mathrm{~nm}$ $\left(\mathrm{Mn}^{\mathrm{IV}}(\mathrm{OH})(\mathrm{OTf})\left(\mathrm{TBP}_{8} \mathrm{Cz}^{\bullet+}\right)\right.$, red dots $)$ in $\mathrm{PhCN}$ at $298 \mathrm{~K}$. 
(a)

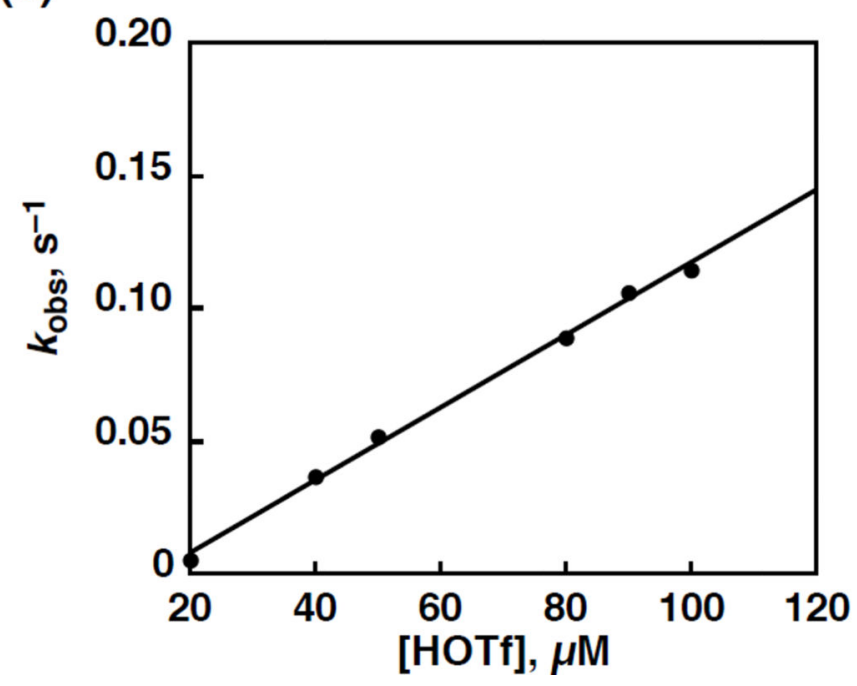

(b)

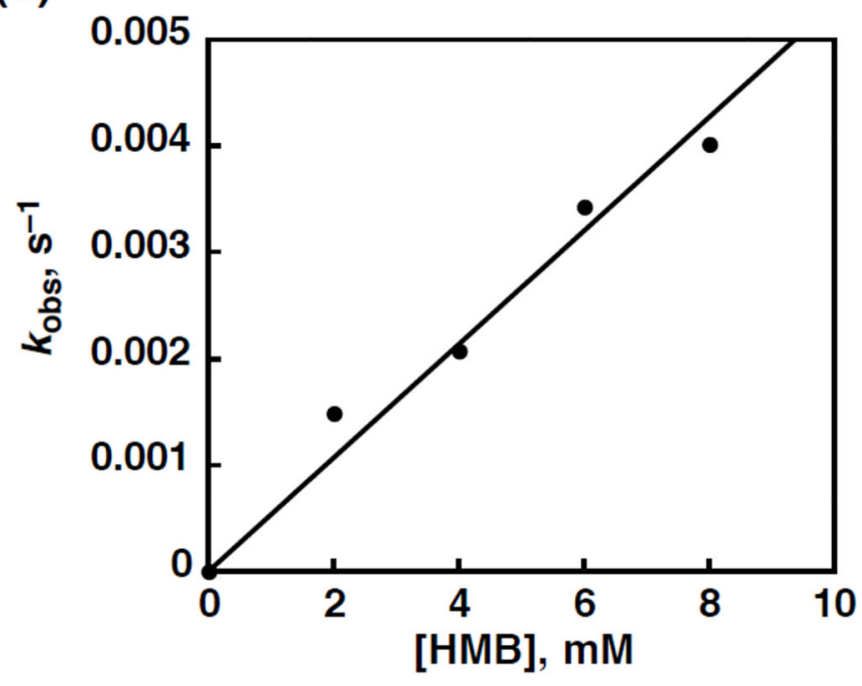

Figure 10.

(a) Plot of the observed pseudo-first-order rate constant $\left(k_{\mathrm{obs}}\right)$ vs concentrations of HOTf for the oxidation of $\mathrm{HMB}\left(2.0 \times 10^{-2} \mathrm{M}\right)$ by $\mathrm{Mn}^{\mathrm{V}}(\mathrm{O})\left(\mathrm{TBP}_{8} \mathrm{Cz}\right)\left(1.0 \times 10^{-5} \mathrm{M}\right)$ in the presence of HOTf $\left(2.0 \times 10^{-5}-1.0 \times 10^{-4} \mathrm{M}\right)$ in $\mathrm{PhCN}$ at $298 \mathrm{~K}$. (b) Plot of the observed pseudofirst-order rate constant $\left(k_{\text {obs }}\right)$ vs concentrations of HMB for the oxidation of HMB $(0-1.0$ $\left.\times 10^{-2} \mathrm{M}\right)$ by $\mathrm{Mn}^{\mathrm{V}}(\mathrm{O})\left(\mathrm{TBP}_{8} \mathrm{Cz}\right)$ in the presence of HOTf $\left(3.0 \times 10^{-5} \mathrm{M}\right)$ in PhCN at $298 \mathrm{~K}$. 


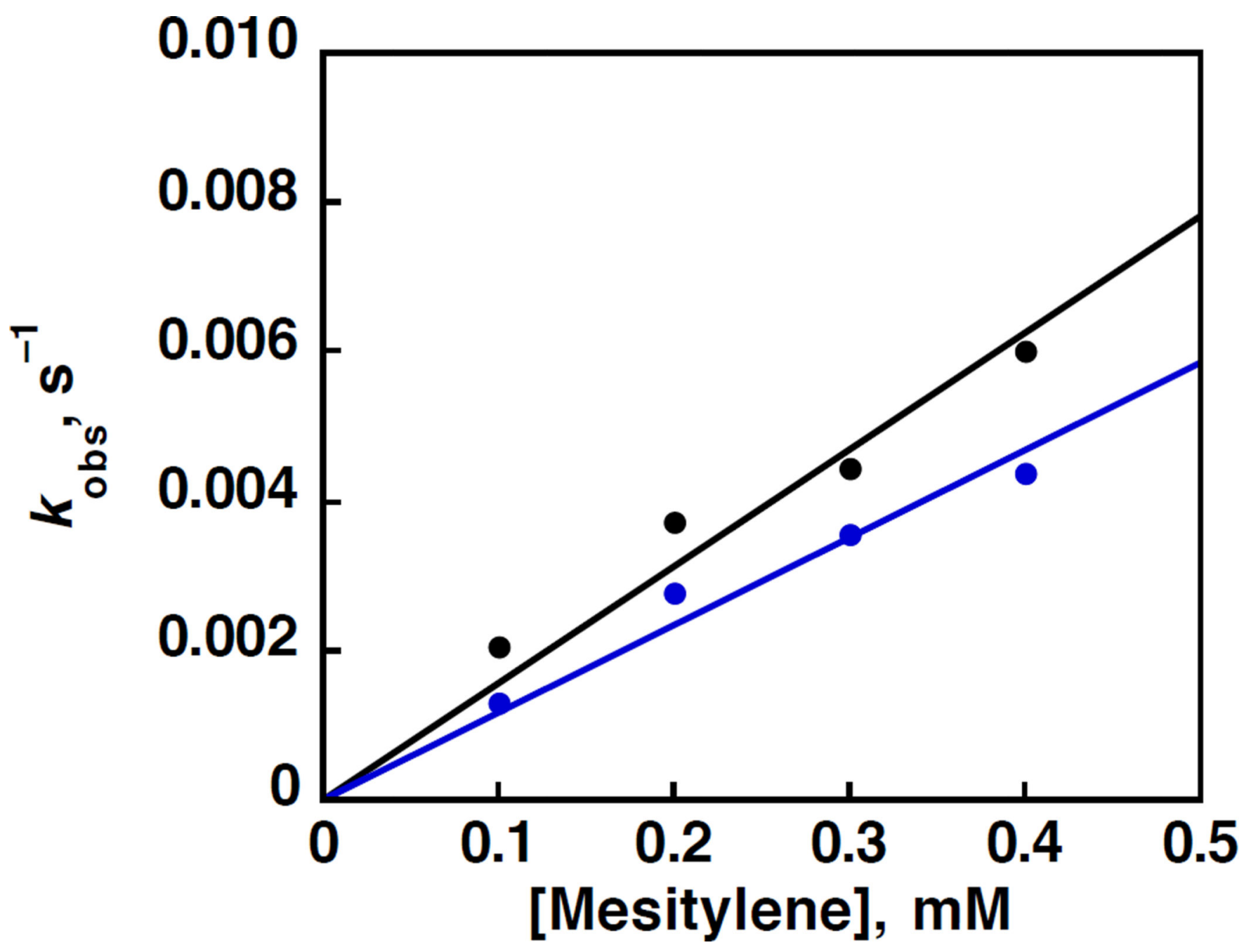

Figure 11.

Plots of pseudo-first-order rate constants vs concentrations of mesitylene $\left(\mathrm{C}_{6} \mathrm{H}_{3}\left(\mathrm{CH}_{3}\right)_{3}\right)$ (black) and mesitylene- $d_{12}\left(\mathrm{C}_{6} \mathrm{D}_{3}\left(\mathrm{CD}_{3}\right)_{3}\right)$ (blue) in the oxidation of $\mathrm{C}_{6} \mathrm{H}_{3}\left(\mathrm{CH}_{3}\right)_{3}$ and $\left(\mathrm{C}_{6} \mathrm{D}_{3}\left(\mathrm{CD}_{3}\right)_{3}\right)$ by $\mathrm{Mn}^{\mathrm{V}}(\mathrm{O})\left(\mathrm{TBP}_{8} \mathrm{Cz}\right)\left(3.0 \times 10^{-5} \mathrm{M}\right)$ in the presence of HOTf $\left(1.5 \times 10^{-4} \mathrm{M}\right)$ in $\mathrm{PhCN}$ at $298 \mathrm{~K}$. 


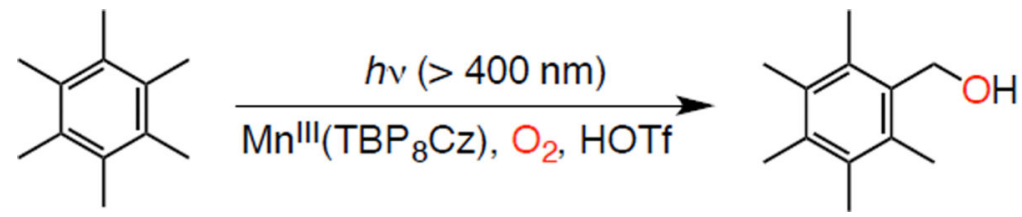

Scheme 1.

Catalytic Oxygenation of Hexamethylbenzene by $\mathrm{O}_{2}$ with $\mathrm{Mn}^{\mathrm{III}}\left(\mathrm{TBP}_{8} \mathrm{Cz}\right)$ and HOTf under Photoirradiation Conditions 
<smiles>CSc1ccccc1</smiles><smiles>CC(C)[Pb]C(=O)OOC(=O)O</smiles><smiles>CS(=O)c1ccccc1</smiles>

Scheme 2.

Catalytic Oxygenation of Thioanisole by $\mathrm{O}_{2}$ with $\mathrm{Mn}^{\mathrm{III}}\left(\mathrm{TBP}_{8} \mathrm{Cz}\right)$ and HOTf under Photoirradiation Conditions 


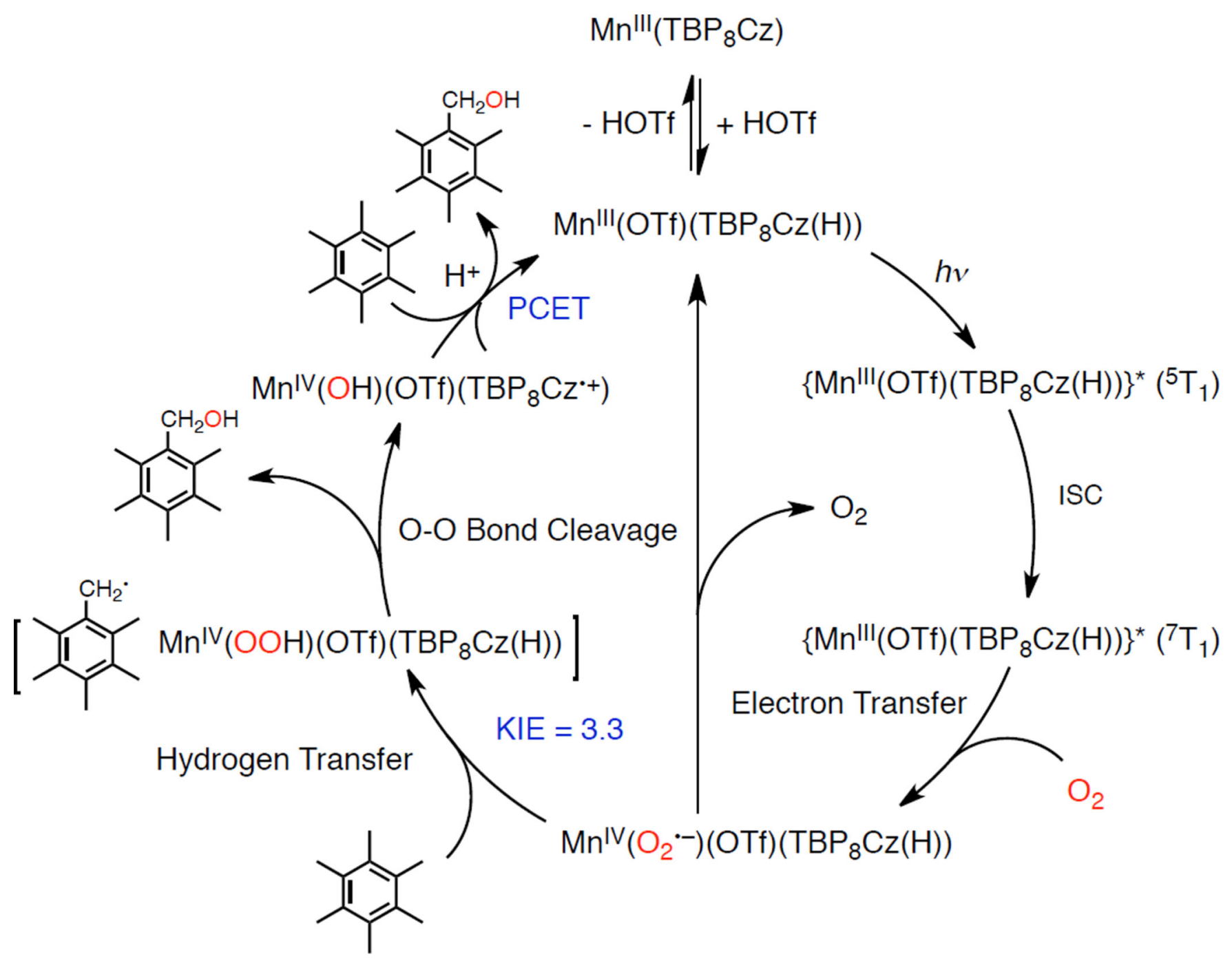

Scheme 3.

Mechanism of Photocatalytic Oxygenation of HMB by 1 with $\mathrm{O}_{2}$ 
$\mathrm{Mn}^{\mathrm{III}}(\mathrm{OTf})\left(\mathrm{TBP}_{8} \mathrm{Cz}(\mathrm{H})\right)$

- HOTf $\downarrow+$ HOTf

$\left[\mathrm{Mn}^{\text {III }}(\mathrm{OTf})\left(\mathrm{H}_{2} \mathrm{O}\right)\left(\mathrm{TBP}_{8} \mathrm{Cz}(\mathrm{H})_{2}\right)\right][\mathrm{OTf}]$

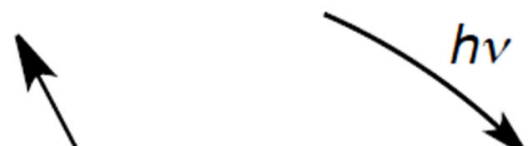

$\left\{\left[\mathrm{Mn}^{\mathrm{III}}(\mathrm{OTf})\left(\mathrm{H}_{2} \mathrm{O}\right)\left(\mathrm{TBP}_{8} \mathrm{Cz}(\mathrm{H})_{2}\right)\right][\mathrm{OTf}]\right\}^{*}\left({ }^{5} \mathrm{~T}_{1}\right)$
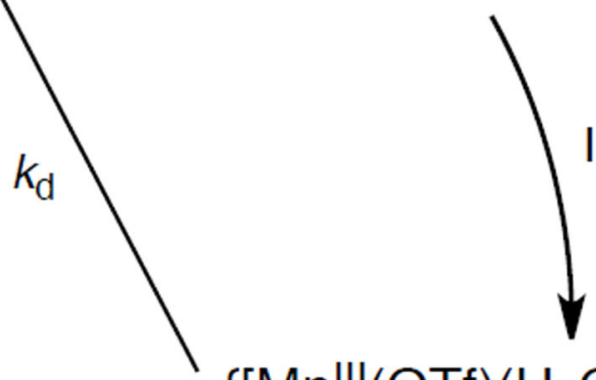

$\left\{\left[\mathrm{Mn}^{\mathrm{III}}(\mathrm{OTf})\left(\mathrm{H}_{2} \mathrm{O}\right)\left(\mathrm{TBP}_{8} \mathrm{Cz}(\mathrm{H})_{2}\right)\right][\mathrm{OTf}]\right\}^{*}\left({ }^{7} \mathrm{~T}_{1}\right)$
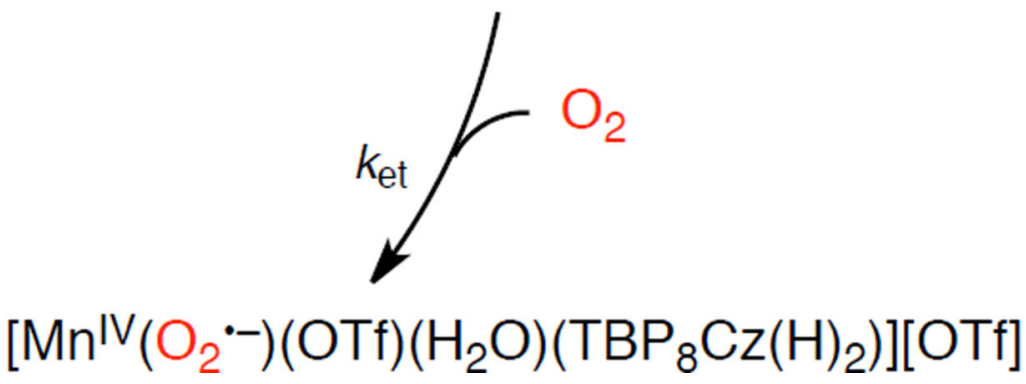

\section{Scheme 4.}

Mechanism of Photocatalytic Oxygenation of HMB by $\mathbf{2}$ with $\mathrm{O}_{2}$ 